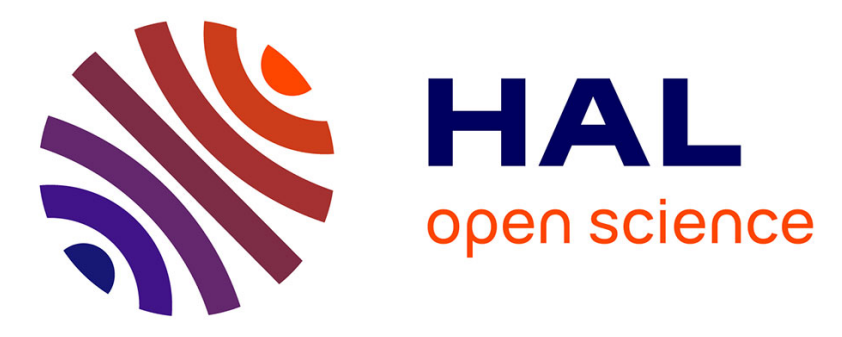

\title{
Bioaccumulation of Lithium Isotopes in Mussel Soft Tissues and Implications for Coastal Environments
} Fanny Thibon, Marc Metian, François Oberhänsli, Maryline Montanes, Emilia

Vassileva, Anna Maria Orani, Philippe Telouk, Peter Swarzenski, Nathalie Vigier

\section{To cite this version:}

Fanny Thibon, Marc Metian, François Oberhänsli, Maryline Montanes, Emilia Vassileva, et al.. Bioaccumulation of Lithium Isotopes in Mussel Soft Tissues and Implications for Coastal Environments. ACS Earth and Space Chemistry, 2021, 5 (6), pp.1407-1417. 10.1021/acsearthspacechem.1c00045 . hal-03405883

\section{HAL Id: hal-03405883 \\ https://hal.science/hal-03405883}

Submitted on 27 Oct 2021

HAL is a multi-disciplinary open access archive for the deposit and dissemination of scientific research documents, whether they are published or not. The documents may come from teaching and research institutions in France or abroad, or from public or private research centers.
L'archive ouverte pluridisciplinaire HAL, est destinée au dépôt et à la diffusion de documents scientifiques de niveau recherche, publiés ou non, émanant des établissements d'enseignement et de recherche français ou étrangers, des laboratoires publics ou privés. 
1 Bioaccumulation of lithium isotopes in mussel soft tissues and implications for coastal environments

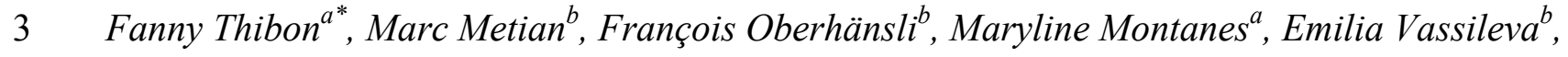
$4 \quad$ Anna Maria Orani ${ }^{b}$, Philippe Telouk ${ }^{c}$, Peter Swarzenski ${ }^{b}$ and Nathalie Vigier $^{a}$

6 a Laboratoire d'Océanographie de Villefranche-sur-Mer (LOV), CNRS UMR 7093, Sorbonne

7 université, 06230 Villefranche-sur-Mer, France

$8{ }^{\mathrm{b}}$ International Atomic Energy Agency (IAEA), Environment Laboratories, 4a, Quai Antoine Ier,

9 MC-98000 Principality of Monaco, Monaco

$10{ }^{\mathrm{c}}$ Laboratoire de Géologie de Lyon, Ecole Normale Supérieure de Lyon, CNRS UMR 5276,

11 Université de Lyon, 46 Allée d'Italie, 69007 Lyon, France 


\section{ABSTRACT}

14 Lithium production has dramatically increased over the past decade, and first cases of 15 environmental Li pollution have been recently reported in urban and in mining regions. While 16 elevated $\mathrm{Li}$ concentrations may be toxic for living organisms, tools to monitor $\mathrm{Li}$ in the

17 environment have not yet been developed. Consequently, its impact on key biota and human

18 health is still poorly known. The present laboratory-based study shows that the soft tissue of blue 19 mussels (Mytilus edulis) can be used to quantify Li contamination in coastal waters. Stable Li

20 isotope ratios $\left({ }^{7} \mathrm{Li} /{ }^{6} \mathrm{Li}\right)$ measured in these soft tissues correlate positively with seawater $\mathrm{Li}$

21 concentrations and show precisely the threshold above which mussels shift their depuration

22 mechanism. Combined with other data from the natural environment, the experimental results

23 have profound implications for the fate of coastal ecosystems and shellfish consumption living

24 under high Li environmental level. We also highlight the need to develop innovative tools to

25 extract Li from wastewaters before its release into rivers and, ultimately, the ocean.

\section{KEYWORDS}

27 Bivalves, Lithium, Isotopic tools, Emerging contaminant, Fractionation, Concentration effects 


\section{Introduction}

31 Lithium (Li) occurs naturally at trace levels in the environment. Consequently, it is also present

32 in living organisms, and some studies have even suggested that Li should be recognized as an

33 essential element ${ }^{1}$. However, as observed for other metals ${ }^{2,3}, \mathrm{Li}$ is toxic and can eventually be

34 lethal beyond a specific threshold ${ }^{4-6}$. Elevated levels of $\mathrm{Li}$ in the aquatic environment can be due

35 to natural inputs, mainly from rock erosion ${ }^{7}$, but they can also be related to anthropogenic

36 activities. There is an increasing demand of Li from high-tech industries producing Li-rich

37 batteries for laptops, mobiles, and other electronic devices worldwide. The Li production has

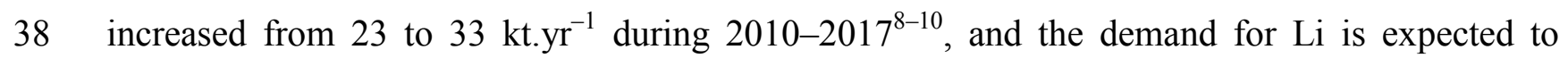

39 follow the greatest growth trajectory among all metals by $2025^{9}$. Li contamination has already

40 been observed in groundwater and river water with close proximity to mining sites ${ }^{11}$, as well as

41 in municipal waters of a modern and densely populated metropolitan area ${ }^{12}$. This is a worrying

42 problem as the various protocols of wastewater depuration appear to be inefficient ${ }^{12}$ at removing

43 Li because of the high mobility of $\mathrm{Li}$ and its poor ability to adsorb onto particle surfaces ${ }^{13}$ ( $\mathrm{Li}$

44 was used as an aquifer water flux $\operatorname{tracer}^{14,15}$ ). In addition, there is no major Li sink in estuaries

45 and, therefore, dissolved $\mathrm{Li}$ is conservatively delivered to littoral waters and to the ocean ${ }^{16,17}$.

46 Overall, there is a growing concern on the fate of global Li increase in the environment,

47 especially the risk of this emerging aquatic pollution on organisms and humans that consume

48 them.

49 Li monitoring in the marine environment is not commonly performed as compared to other trace

50 metals $^{18-20}$. For instance, mussel-based biomonitoring programs ${ }^{21-23}$ do not include Li in the 
51 chemicals analyzed, even if mussels, along with other shellfish and bivalves, contain more Li

52 than any other species from higher trophic levels ${ }^{24}$. The paucity of information on the process of

$53 \mathrm{Li}$ accumulation in marine coastal organisms needs to be addressed to better understand the

54 response, the fate, and the risk of $\mathrm{Li}$ contamination in the marine environment, as well as for

55 potential human health implications.

56 To better comprehend the biological mechanisms at play, it is possible to measure precisely the

57 natural variations of $\mathrm{Li}$ stable isotope ratios $\left({ }^{6} \mathrm{Li}\right.$ and ${ }^{7} \mathrm{Li}$, abundances of $7.59 \%$ and $92.41 \%$,

58 respectively). Stable isotopes of trace metals are valuable tools to investigate subtle

59 physiological changes in organisms ${ }^{25-28}$. However, Li isotopes in marine organisms were, so far,

60 not used due to technical limitations related to low $\mathrm{Li}$ levels in tissues ${ }^{29}$. Yet, being able to

61 measure and track $\mathrm{Li}$ isotopes in this manner (1) will help understand how they are affected by

62 homeostatic processes and elevated Li levels in the environment, and (2) will also benefit paleo-

63 oceanographic studies wherein Li has proven utility. Indeed, Li isotopes are now widely used to

64 reconstruct past ocean and climate by analyzing fossil carbonates formed by calcifying

65 organisms ${ }^{30-34}$. However, the role and impact of biological processes ('vital effects') on these

66 biogenic minerals still remain an open question ${ }^{35-38}$, which leads to a high level of uncertainties

67 concerning Earth's climate regulation after a disturbance, such as from a meteorite impact or a

68 mass extinction ${ }^{39}$.

69 Here, we exposed blue mussels (Mytilus edulis) to various degrees of environmental Li

70 enrichment during laboratory experiments. We report $\mathrm{Li}$ concentrations and $\mathrm{Li}$ isotopes

71 compositions of mussel soft tissues. We aim to define the impact of elevated Li levels in mussel

72 metabolism and, by comparing our results with data collected in the natural environment, to

73 evaluate the mussel ability to biomonitor $\mathrm{Li}$ contamination. We also highlight the Li 
74 environmental concentration limit that defines risk for bivalves and assess implications of

75 elevated Li concentrations for coastal organisms and population.

77 Materials and Methods

\section{Experimental setting and sample preparation}

80 A summary of the experimental setting is sketched in Fig. S1. Forty individual common blue

81 mussels (Mytilus edulis) of similar size $(43.01 \pm 2.18 \mathrm{~mm})$ and wet weight $(7.137 \pm 1.014 \mathrm{~g})$

82 were collected in summer 2019 (outside spawning period) in situ from La Rochelle, Bay of

83 Biscay, France. The experiment was performed at the Environment Laboratories of the

84 International Atomic Energy Agency (Monaco), based on well-established protocols. Mussels

85 were acclimated at the laboratory environment for one month, at $20.5^{\circ} \mathrm{C}$. Batches of five mussels

86 were placed in eight 5-L glass beakers filled with $2 \mathrm{~L}$ of filtered (1 um) seawater pumped from

87 the 30m water depth in Mediterranean Sea (Monaco Bay). Seawater salinity, temperature, and

$88 \mathrm{pH}_{\mathrm{T}}$ were $39 \pm 1,20.5 \pm 0.5^{\circ} \mathrm{C}$, and $8.03 \pm 0.05$, respectively. Water oxygenation was ensured

89 by constant air bubbling, and a $12 \mathrm{~h}-12 \mathrm{~h}$ light-dark cycle was established.

90 Two duplicates (A and B) of four experimental conditions were implemented with increasing

91 seawater Li concentrations: CTRL (control group, $\left.\sim 0.18 \mathrm{mg} \mathrm{Li} \mathrm{L}^{-1}\right)$, Li-0.5 $\left(\sim 0.5 \mathrm{mg} \mathrm{Li} \mathrm{L}{ }^{-1}\right), \mathrm{Li}^{-}$

$921.0\left(\sim 1.0 \mathrm{mg} \mathrm{Li} \mathrm{L}{ }^{-1}\right)$, and $\mathrm{Li}-1.5\left(\sim 1.5 \mathrm{mg} \mathrm{Li} \mathrm{L}^{-1}\right)$. To obtain the desired Li concentrations,

93 dedicated volumes of a concentrated Li reference solution (1000 $\mathrm{mg} \mathrm{Li} \mathrm{L}^{-1}$, ICP Standard) were

94 evaporated and added as solid salt to the filtered seawater.

95 The mussels were kept in their experimental aquaria during 4 days, and the culture media

96 (seawater with different Li concentrations) were renewed every day at the same time (13:40 \pm 40 
$97 \mathrm{~min}$ ). Due to the paucity of data on Li bioaccumulation process, we decided (1) to investigate the

98 short time process in order to better understand the short term isotope fractionation and uptake

99 processes assuming that $\mathrm{Li}$ should act like other alkali elements (i.e., Cs, which quickly reaches a

100 saturation state when accumulated in marine bivalves ${ }^{40-42}$ ) and (2) to use a relatively high

101 exposure concentration based on data available in freshwater studies ${ }^{4,43}$. Seawater samples were

102 collected before and after each water change to confirm that each aquarium operated as an open

103 system. Between water changes, the mussels were fed for $1 \mathrm{~h}$ using non-contaminated seawater

104 containing phytoplankton Isochrysis galbana at a concentration of $10^{4}$ cells $\mathrm{mL}^{-1}$. One mussel

105 died after 2 days of the experiment in the duplicate A of the CTRL condition. At the end of the

106 experiment, all individuals were collected and rinsed for $30 \mathrm{~min}$ in clean, filtered seawater

107 following the classical protocol for eliminating weakly adsorbed elements from tissue samples ${ }^{44}$.

108 The soft tissues were then extracted, frozen at $-28{ }^{\circ} \mathrm{C}$ for $72 \mathrm{~h}$, and freeze-dried for further 109 analyses.

\section{Analytical methods}

112 To minimize the possibility of any contamination and procedural blanks, all analytical

113 preparations were performed in a positively pressurized clean laboratory under a fume-hood

114 using only distilled, trace-metal grade reagents and pre-cleaned vessels. Each mussel's soft tissue

115 was weighed in a Teflon reactor, then digested in a mixture of $5 \mathrm{~mL} \mathrm{HNO}_{3}$ and $2 \mathrm{~mL} \mathrm{H}_{2} \mathrm{O}_{2}$ (both

116 trace metal grade, Fisher Scientific, USA) at $90{ }^{\circ} \mathrm{C}$ for $\sim 5 \mathrm{~h}$. The obtained solutions were

117 transferred into pre-cleaned polyethylene tubes and gravimetrically diluted up to $20 \mathrm{~g}$ with

118 MilliQ water (18 M $\Omega$ ). Two procedural blanks and two replicates of the Certified Reference

119 Material (CRM) IAEA 407 (Fish Homogenate, IAEA, Vienna) were included in the digestion 
120 batch and analyzed with the samples. The recoveries obtained for the CRM were $95 \pm 3 \%$. For

121 each sample, two solution aliquots were separated for elemental and isotopic analyses.

122 Lithium concentrations were determined at the IAEA in Monaco by flame atomic absorption 123 spectroscopy using a ContrAA 700 (Analytic Jena, Germany). The applied analytical procedure 124 was based on external calibration approach and was preliminary validated, according to the 125 requirements of international guidelines for method validation ${ }^{45}$. Calibration curves were daily 126 prepared using proper dilution of commercially available standard solutions. All possible sources 127 of uncertainty of obtained results were carefully identified. The numerical method of 128 differentiation described by Kragten ${ }^{46}$ was used to calculate combined standard uncertainties of 129 obtained measurement results.

130 Prior to Li isotopic analyses, the Li in the samples must be purified. Lithium extraction and 131 purification were performed following the procedure of Vigier et al. ${ }^{47}$, summarized here. 132 Sample solution aliquots were dried out and taken up in $0.5 \mathrm{~mL}$ of $1 \mathrm{~N} \mathrm{HCl}$ and loaded on $\mathrm{AG}$ 133 50-X12 cationic resin in 8.5-cm-high Teflon columns. Lithium was purified twice with $1 \mathrm{~N} \mathrm{HCl}$.

134 This fraction was evaporated to dryness before the analysis.

135 Lithium has two naturally occurring isotopes, one heavy ( ${ }^{7} \mathrm{Li}, 92.41 \%$ abundance) and one light $136\left({ }^{6} \mathrm{Li}, 7.59 \%\right.$ abundance). The isotopic compositions of geological and biological materials are 137 reported as per-mil variations relative to an isotopic standard (here LSVEC) as $\delta^{7} \mathrm{Li}_{\text {sample }}[\%]=$ $138\left(\left({ }^{7} \mathrm{Li} /{ }^{6} \mathrm{Li}\right)_{\text {sample }} /\left({ }^{7} \mathrm{Li} /{ }^{6} \mathrm{Li}\right)_{\mathrm{LSVEC}}-1\right) \times 1,000$.

139 Lithium isotopic analyses were performed at the CNRS-INSU National Service based at the 140 École Normale Supérieure de Lyon (France) using a Thermo-Fisher Neptune Plus multi141 collector inductively coupled plasma mass spectrometer following the procedure of Balter and 142 Vigier $^{29}$ and Bastian et al. ${ }^{48}$ developed for low Li concentrations in biological materials. In brief, 
143 samples and standards were analyzed under dry plasma conditions in low-resolution mode.

144 Instrumental mass bias correction was performed externally using the standard bracketing 145 method (using the LSVEC reference material). Analytical blanks, as well as total procedural 146 blanks, were found to be negligible. The internal reproducibility was on average $\pm 0.04 \%$.

147 Precision (external reproducibility), estimated from two to three replicate measurements of 14 148 different samples (mussels and water), ranged from 0.04 to $1.91 \%$ with an average of $\pm 0.5 \%$. In 149 general, the accuracy of reported isotopic compositions are estimated based on analyses of 150 reference materials of known isotopic composition. However, the Li isotopic compositions of 151 biological reference materials corresponding to soft tissue have never been characterized. Thus, 152 this study reports for the first time the Li isotopic composition of a soft-tissue biological 153 reference material IAEA $407\left(\delta^{7} \mathrm{Li}=28.3 \pm 1.7 \%, 2 \mathrm{SD}, \mathrm{n}=2\right)$. For comparison, the

154 reproducibility of $\delta^{7} \mathrm{Li}$ obtained for the Li7-N non-biological reference material was $0.4 \%$ (2SD, $155 \mathrm{n}=22)^{48}$. Note that the IAEA 407 contain $0.68 \pm 0.1 \mu \mathrm{g} \mathrm{Li} \mathrm{g}^{-1}$ of dry powder, while Li7-N is an 156 isotopically homogeneous solution, analyzed at a $\mathrm{Li}$ concentration of $4 \mathrm{ng} \mathrm{mL} \mathrm{m}^{-1}$.

\section{Statistical treatment}

159 Since the Li data were not normally distributed (i.e., Li concentration and $\mathrm{Li}$ isotope ratios do not 160 follow a normal law), we adopted non-parametric statistical tests. The Mann-Whitney-Wilcoxon 161 test was used to compare median values between two observational series, and the Kruskal-

162 Wallis test was used to compare three or more series. Tests were performed using R software ${ }^{49}$ 163 using the respective functions wilcox.test and kruskal.test. The level of significance for statistical 164 analyses was set at $p<0.05$. 
165 The relationship between quantitative variables was investigated using principal component 166 analysis (PCA, see section 4.3), a statistical tool that reduces the number of original quantitative 167 variables to fewer dimensions that may explain the majority of the observed variability. Here, 168 PCA was performed using $\mathrm{R}$ software ${ }^{49}$ considering the following variables: $\mathrm{Al}, \mathrm{B}, \mathrm{Ca}, \mathrm{Fe}, \mathrm{K}$, $169 \mathrm{Li}, \mathrm{Mg}, \mathrm{Mn}, \mathrm{Na}, \mathrm{Si}$, and $\mathrm{Sr}$ concentrations in mussels, the $\mathrm{Li}$ concentration in seawater $\left(\mathrm{Li}_{\mathrm{sw}}\right)$, 170 and $\Delta^{7} \mathrm{Li}_{\text {mussel-water }}$.

171

$172 \underline{\text { Results }}$

173

174 In the control group 'CTRL', the aquarium seawater Li concentration was $0.18 \mu \mathrm{g} \mathrm{mL}^{-1}$, which 175 corresponds to the mean global ocean Li concentration ${ }^{50}$. Li concentrations in seawater were set 176 at $0.5,1.0$, and $1.5 \mu \mathrm{g} \mathrm{mL} \mathrm{m}^{-1}$ in the ' $\mathrm{Li}-0.5$ ', ' $\mathrm{Li}-1.0^{\prime}$ ', and ' $\mathrm{Li}-1.5$ ' treatments, respectively. The $\mathrm{Li}$ 177 water concentration error is estimated at 10\% (2SD). After the experiment, Li concentrations 178 measured in mussels soft tissues were $0.45 \pm 0.18$ for the CTRL group (2SD, $n=9), 1.20 \pm 0.53$ $179(2 \mathrm{SD}, \mathrm{n}=10), 1.54 \pm 0.96(2 \mathrm{SD}, \mathrm{n}=10)$, and $2.19 \pm 1.65 \mu \mathrm{g} \mathrm{g}^{-1}(2 \mathrm{SD}, \mathrm{n}=10)$, for the 'Li-0.5', 180 'Li-1.0', and 'Li-1.5' treatments, respectively (Fig. 1A, Table S2). This corresponds to a fivefold 181 increase of the average mussel $\mathrm{Li}$ concentration between CTRL and $\mathrm{Li}-1.5$, in response to an 182 eightfold increase of the seawater Li concentration.

183 Due to the different isotopic compositions in seawater $\left(\delta^{7} \mathrm{Li}=31.2 \pm 0.3 \%\right.$ in the open 184 ocean $\left.^{50,51}\right)$ and the pure $\mathrm{Li}$ solution $\left(\delta^{7} \mathrm{Li}=10.8 \%\right.$ ) used to prepare the three exposure conditions, 185 the mussels in each group were exposed to seawater with different $\mathrm{Li}$ isotopic compositions $186\left(\delta^{7} \mathrm{Li}_{\mathrm{sw}}\right.$, which remained constant over the course of the experiment; Table S1): $\delta^{7} \mathrm{Li}_{\mathrm{sw}}{ }^{\mathrm{CTRL}}=31.5$ $187 \pm 0.7 \%$ o (2SD, $n=5), \delta^{7} \mathrm{Li}_{\mathrm{sw}}{ }^{\mathrm{Li}-0.5}=18 \%$ (calculated), $\delta^{7} \mathrm{Li}_{\mathrm{sw}}{ }^{\mathrm{Li}-1.0}=14.6 \pm 0.01 \%$ o $(2 \mathrm{SD}, n=2)$, 
188 and $\delta^{7} \mathrm{Li}_{\mathrm{sw}}{ }^{\mathrm{Li}-1.5}=13.4 \pm 0.1 \%$ o $(2 \mathrm{SD}, n=5)$. These compositions fit along a binary mixing curve

189 (cf. following sections), which demonstrates that, despite a significant Li incorporation by

190 mussels, it remains negligible when compared to the total water Li content of each aquarium. As

191 a consequence, it does not modify neither the water Li content, nor its $\delta^{7} \mathrm{Li}$ value.

192 The average $\delta^{7} \mathrm{Li}$ of mussel soft tissues in groups Li-1.0 and Li-1.5 were 21.0 $\pm 2.6 \%$ and $21.6 \pm$ 193 2.7\%o, respectively (Table S2, Fig. 1B). The one in group Li-0.5, significantly higher than the 194 latest $(24.4 \pm 3.4 \%$, Wilcoxon test, $p<0.001)$ was significantly lower than that in the control 195 group $(31.7 \pm 2.0 \%$, Wilcoxon test, $p<0.0001)$.

197 Discussion

\section{Li bioaccumulation by mussels}

200 At the end of the experiment, the $\mathrm{Li}$ concentrations measured in mussels of the control group

$201\left(0.45 \pm 0.18 \mu \mathrm{g} \mathrm{g}^{-1}\right)$ were consistent with that observed in bivalve tissues and organs collected 202 along the French Atlantic coast $\left(0.43 \pm 0.25 \mu \mathrm{g} \mathrm{g}^{-1}\right)^{52}$. This result supports the representative 203 nature of our samples, the reliability of our methods, as well as the lack of bias related to the 204 experimental setup. In both cases (in experiments and in nature), mussel Li concentrations are 205 significantly higher than in seawater $\left(0.18 \mu \mathrm{g} \mathrm{mL}^{-1}\right)$, by a factor of 2.5 on average. This agrees 206 well with a recent study ${ }^{24}$ that shows that bivalves, and filter feeders in general, accumulate Li 207 the most compared to other organisms from higher trophic groups, such as crustaceans, 208 cephalopods, and fish.

209 The average Li concentrations displayed by mussels exposed to Li-rich seawater are statistically 210 higher than those of the control group, and increase with seawater Li concentrations, up $2.19 \pm$ 
$2111.65 \mu \mathrm{g} \mathrm{g}^{-1}$ when the water Li content is $1.5 \mu \mathrm{g} \mathrm{mL}^{-1}$ (Figs. $1 \mathrm{~A}$ and 2A). This demonstrates that, 212 on average, mussels accumulate $\mathrm{Li}$ proportionally to the concentrations found in their 213 environment, which is a major criterion to validate a biota as a reliable bioindicator of 214 contamination $^{53}$. These results are consistent with a recent laboratory study that explored key 215 biochemical parameters changed by long-term (28 days) Li exposure on mussels. At 0.25 and $2160.75 \mathrm{mg} \mathrm{Li} \mathrm{L}^{-1}$ in aquarium water, the mussel Li concentrations were found to be $0.9 \pm 0.23 \mu \mathrm{g}$ $217 \mathrm{~g}^{-1}$ and $1.4 \pm 0.23 \mu \mathrm{g} \mathrm{g}^{-1}$, respectively. These data perfectly fit with our short-term exposure 218 results (Figure 2A), supporting that a bioaccumulation steady-state was reached within the 4-day 219 exposure. The ability of bivalves to bioaccumulate Li can also be evidenced along the coast of 220 North Chile (Table 1). Indeed, this coastal area is characterized by an unusually elevated Li 221 concentration from river waters draining the high altitude Salars (salt flats). When compared to 222 bivalves collected in low Li environments, such as the Atlantic or the Pacific coast, the Chilean 223 bivalves display much higher Li concentrations (by 50 to 270 times higher, see Table 1). Taken 224 altogether (Fig. 2A), all these data are consistent and demonstrate that mussels take up Li in 225 direct proportion to the ambient dissolved concentrations, at least over the range of 226 concentrations tested here.

227 There is a significant variability among individuals, and a striking observation is that this 228 variability of individual Li concentrations increases with seawater Li concentration (from $44 \%$ in 229 the control group to $75 \%$ in Li-1.5; Fig. 1A). This suggests that some mussels, when exposed to 230 elevated $\mathrm{Li}$ concentrations, can better regulate Li uptake than others. This kind of intra231 variability among mussels has already been reported for other trace elements such as $\mathrm{Zn}, \mathrm{Cd}$, and $232 \mathrm{Cu}^{18}$. Thus, a reliable assessment of environmental $\mathrm{Li}$ concentrations requires that several 233 mussels are pooled together to capture the range of individual responses, as this is done for other 
234 contaminants measured in bivalves ${ }^{21-23}$. Based on the range of seawater Li concentration used in

235 this study, we estimate that accurate Li concentration can be obtained with the analyses of at

236 least five individuals, and likely more when water Li concentration exceeds $1.5 \mu \mathrm{g} \mathrm{mL}^{-1}$, such as

237 in Northern Chili (since the variability increases with the Li level, Fig. 2). Existing

238 biomonitoring programs usually collect and pool between 80 and 160 individuals per site ${ }^{54}$, so

239 the use of mussels to monitor Li levels along with other contaminants in coastal areas appear 240 largely feasible.

\section{$242 \quad$ Preferential ${ }^{7}$ Li enrichment in mussels}

243 While the seawater in experimental aquaria have a constant and homogenous $\delta^{7} \mathrm{Li}$ value for each 244 condition, exposed mussels are 'isotopically fractionated' compared to their aquarium water, i.e.

245 with significantly higher $\delta^{7} \mathrm{Li}$ values (Fig. 2B). This indicates that mussels preferentially 246 accumulate the heavy $\left({ }^{7} \mathrm{Li}\right)$ isotope in their soft-parts, as compared to the light $\left({ }^{6} \mathrm{Li}\right)$ isotope. It is 247 possible to calculate the corresponding water-mussel $\mathrm{Li}$ isotopic fractionations $\left(\Delta^{7} \mathrm{Li}_{\text {mussel-water }}\right)$ 248 using $^{55}$ :

$249 \quad \Delta^{7} \mathrm{Li}_{\text {mussel-water }}(\%)=\delta^{7} \mathrm{Li}_{\text {mussel }}-\delta^{7} \mathrm{Li}_{\text {water }}$

$250 \Delta \Delta^{7} \mathrm{Li}_{\text {mussel-water }}$ value near $0 \%$ indicates no $\mathrm{Li}$ isotopic fractionation, since mussel $\delta^{7} \mathrm{Li}$ is equal to $251 \quad$ water $\delta^{7} \mathrm{Li}$.

252 At the end of the exposition, the average $\Delta^{7} \mathrm{Li}_{\text {mussel-water }}$ ranges from $0.0 \%$ to $+10.3 \%$ (Fig. $2 \mathrm{~B}$ ).

253 Mussels in the control group exhibit a mean $\delta^{7} \mathrm{Li}$ value similar to that of the seawater (with $254 \Delta \Delta^{7} \mathrm{Li}_{\text {mussel-water }}=+0.4 \pm 0.9 \%$ o, $\mathrm{SD}, n=8$ ), whereas the average $\Delta^{7} \mathrm{Li}_{\text {mussel-water }}$ values of the other 255 experimental groups increase from $+5.7 \pm 2.1 \%$ to $+7.5 \pm 3.2 \%$ (from $\mathrm{Li}-0.5$ to $\mathrm{Li}-1.5$ 256 respectively). Li isotopic fractionation is the strongest with the very first - limited - increment in 
257 Li enrichment (5.7\% in Li-0.5 condition vs. $0.4 \%$ in CTRL group). Further increases in seawater

$258 \mathrm{Li}$ concentration still result in significant (Wilcoxon test, $p<0.05$ ), but lower, isotope

259 fractionation (up to $7.5 \%$ in $\mathrm{Li}-1.5$ ). This indicates that mussel $\delta^{7} \mathrm{Li}$ value increases with $\mathrm{Li}$

260 contamination and suggests that even an exposition to a small degree of contamination has a

261 strong and significant effect on mussel $\mathrm{Li}$ isotopic compositions. The Li isotopic compositions of

262 mussel soft tissues can therefore reveal even very subtle effects related to environmental $\mathrm{Li}$

263 contamination, which further supports the possibility to use mussel Li isotope ratio to monitor

264 the Li level in waters. Measuring the isotopic composition of mussels has the advantage that

265 there is small $\mathrm{Li}$ isotopic variability among mussel individuals and a representative $\delta^{7} \mathrm{Li}$ value

266 requires 2 individuals only (for a $2-3 \%$ uncertainty), in contrast to Li concentration. Variabilities

267 exists for isotopic composition, but their magnitude is only of few permill maximum. A recent

268 study shows that the isotopic composition of anthropogenic $\mathrm{Li}$ in waters can be distinct from that

269 of natural $\mathrm{Li}^{12}$. Thus, further investigation appears necessary to provide a methodology to trace

270 both Li levels and Li sources (natural or anthropogenic) in the environment.

\section{Li biological control}

273 The biological processing of $\mathrm{Li}$ in mussels is affected by the $\mathrm{Li}$ concentration in the environment

274 because the mussel-water $\mathrm{Li}$ isotope fractionation increases with dissolved Li concentration. The

275 observed ${ }^{7} \mathrm{Li}$ (heavy) enrichment of mussel soft tissue relative to seawater is intriguing as, in

276 most isotopic systems, biological isotopic fractionation favor light isotopes, mostly because of

277 kinetic effects during ionic transport. Recent work reveals that Li transport in cells, either passive

278 or active, is related to a preferential and significant enrichment in ${ }^{6} \mathrm{Li}^{56}$. $\mathrm{Li}$ has been considered

279 to be analogous to $\mathrm{Na}$ in cells because of the chemical proximity and monovalence of both alkali 
280 elements. Indeed, $\mathrm{Li}$ is transported by $\mathrm{Na}^{+} / \mathrm{H}^{+}$ubiquitous exchangers (NHEs), which control 281 intracellular $\mathrm{pH}^{57-60} . \mathrm{Ca} / \mathrm{Na}$ exchangers, likely involved in carbonate shell growth, are also 282 known to transport $\mathrm{Li}^{61,62}$. To verify the potential link between $\mathrm{Li}, \mathrm{Na}$, and $\mathrm{Ca}$, we measured $283 \mathrm{Li} / \mathrm{Na}$ and $\mathrm{Li} / \mathrm{Ca}$ ratios in every individual mussel. Both $\mathrm{Li} / \mathrm{Na}$ and $\mathrm{Li} / \mathrm{Ca}$ ratios in mussels are 284 positively correlated with $\Delta^{7} \mathrm{Li}_{\text {mussel-water }}$ (Fig. 3). When the $\mathrm{Li} / \mathrm{Na}$ and $\mathrm{Li} / \mathrm{Ca}$ ratios are low, the 285 observed $\mathrm{Li}$ isotopic fractionations are small or negligible $\left(\Delta^{7} \mathrm{Li}_{\text {mussel-water }} \approx 0 \%\right.$ ), whereas the

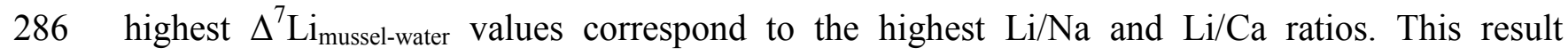
287 confirms the biological coupling between $\mathrm{Li}$ and $\mathrm{Na}{ }^{63}$ and suggests that $\mathrm{Li}$ transport by NHEs 288 and $\mathrm{Ca} / \mathrm{Na}$ transporters are at least partly responsible for the measured $\mathrm{Li}$ isotopic compositions. 289 As Ca is a major building block of bivalve shells, this link might partly explain the vital effects 290 observed in the $\mathrm{Li}$ isotopic signatures of biogenic carbonates ${ }^{35-38}$. Published $\mathrm{Li}$ isotopic 291 compositions of bivalve shells, foraminifera calcite, or corals are scarce, and their interpretation 292 remains disputed ${ }^{32,35-38,64}$. A physiological control of Li isotopes was suggested by Dellinger et $293 a a^{35}$ for various species of molluscs, brachiopods, and echinoderms, and by Vigier et al. ${ }^{38}$ and 294 Roberts et al. ${ }^{36}$ for epibenthic foraminifera. All these studies rely on the $\mathrm{Li}$ isotope composition 295 of the organism's shells, being either calcitic or aragonitic. As a first approximation, we can 296 compare the mussel soft part $\delta^{7} \mathrm{Li}$ values of our CTRL group with those reported for M. edulis 297 shells by Dellinger et al. ${ }^{35}$. (Fig. 2B). These shells were collected from mussels living in Cable 298 Bay (northwest Wales, UK), and have been cultured at different temperatures ${ }^{65}$. They all show $299 \delta^{7} \mathrm{Li}$ values noticeably higher than the $\delta^{7} \mathrm{Li}$ values obtained for the soft tissues of our CTRL 300 group (this study). It is surprising as the formation of calcite induces a significant isotope 301 fractionation in favor of the ${ }^{6} \mathrm{Li}^{66}$. However, both mussel groups do not come from the same 302 location and it is not known if the seawater in which they were cultured had a seawater-like $\delta^{7} \mathrm{Li}$ 
303 value and $\mathrm{Li}$ concentration, or if this seawater was contaminated. Although this comparison

304 requires more detailed investigations, all of these results suggest that the temporal variations of

305 ocean Li concentrations may impact both the Li concentrations and the Li isotopic composition

306 of tissues and shells. Since the isotopic investigation of soft tissues is now technically possible

307 with high sensitivity mass spectrometer ${ }^{29}$, it appears invaluable to a better understanding of the

308 vital effects observed in fossils and potentially for refining paleoclimate reconstructions.

\section{$310 \quad$ Tracing Li homeostasis and biological thresholds with Li isotopes}

311 In order to bioaccumulate $\mathrm{Li}$ as shown in Fig. $2 \mathrm{~A}$, the mussel $\mathrm{Li}$ excretion flux ( $\Phi^{\mathrm{Li}}$ out $)$ must have

312 been lower than its uptake flux $\left(\Phi^{\mathrm{Li}}{ }_{\text {in }}\right)$, such that:

$313 R=\frac{\stackrel{\mathrm{Li}}{\text { out }}}{\mathrm{Li}}<1$

314 As shown in Fig. 2B, and described above, mussel $\delta^{7} \mathrm{Li}$ values are systematically higher than

315 seawater $\delta^{7} \mathrm{Li}$ values. However, due to kinetic effects, Li transport through cell membranes is

316 rather expected to favor the light isotope ${ }^{6} \mathrm{Li}^{67}$. It is common to express these isotope variations

317 during transport by the isotope fractionation factor ' $\alpha$ ', which is related to the $\Delta$ notation

318 (equation 1) using: $\Delta^{7} \mathrm{Li} \approx 1,000 \times \ln (\alpha)$. If both, intake (input) and excretion (output) processes

319 favor the light $\left({ }^{6} \mathrm{Li}\right)$ isotope, then both $\alpha_{\text {in }}$ (input) and $\alpha_{\text {out }}$ (output) are lower than $1\left(\Delta^{7} \mathrm{Li}<0\right)$. In

320 that case, mussel ${ }^{7} \mathrm{Li}$ enrichments are possible only if ${ }^{6} \mathrm{Li}$ excretion flux is greater than ${ }^{6} \mathrm{Li}$ uptake

321 flux over the experimental duration (i.e., if $\alpha_{\text {out }}<\alpha_{\text {in, }}$ see Fig. 4 for more details). As the degree

322 of ${ }^{7} \mathrm{Li}$ enrichment is found to increase as a function of the seawater Li concentrations (Fig. 5), the

323 two possible ways to explain these observations are either that (\#1) the ratio between the output 
324 and input fractionation factors $\left(\alpha_{\text {out }} / \alpha_{\text {oin }}\right)$ decreases as a function of seawater Li content, or (\#2)

325 the ratio of the Li output flux to the Li input flux $\left(R_{\phi}\right)$ increases.

326 Using a simple box model (described in Fig. 4 and in the Supplementary Material), it is possible

327 to verify more precisely whether the Li regulation in connection to variable $\mathrm{Li}$ bioaccumulation

328 by organisms is compatible with their isotopic compositions. Considering that Li transport is

329 likely ensured by ubiquitous ion transporters equally present in all Mytilus edulis of similar

330 provenance ${ }^{57-59}$, we assume that all organisms have a similar value for $\alpha_{\text {out }}$ and $\alpha_{\text {in }}$, and therefore

331 favor hypothesis (\#2). With this assumption, and using the equations detailed in the

332 Supplementary Material, the average mussel $\delta^{7} \mathrm{Li}$ value obtained at each condition can be

333 reproduced within uncertainties (Fig. 5). The calculated input and output Li isotope fractionation

334 factors, $\alpha_{\text {in }}$ and $\alpha_{\text {out }}$, are 0.999 and 0.989 respectively, and $R_{\phi}$ is found to increase with increasing

335 seawater Li concentration, as expected (Table S3).

336 This simple model indicates that, even if mussels bioaccumulate $\mathrm{Li}$, their $\mathrm{Li}$ excretion rate

337 increases significantly as Li contamination increases. This balance between input and output

338 depends on the seawater Li level and can be related to Li homeostasis, which varies as a function

339 of Li bioaccumulation, and therefore, of the water contamination. Indeed, the regulation process

340 of a given element can vary according to low or high accumulation scenario, and be caused, for

341 example, by an intense elimination process (excretion), or by storage as an internal inert form of

342 the element (detoxification process).

343 It is possible to investigate further this aspect by exploring the small but significant $\delta^{7} \mathrm{Li}_{\text {mussel }}$

344 variability displayed by individuals from the same experimental group. For each condition,

345 individual $\Delta^{7} \mathrm{Li}_{\text {mussel-water }}$ values correlate linearly with the $\mathrm{Li}$ enrichment factor $\left(\mathrm{Li}_{\mathrm{m}} / \mathrm{Li}_{\mathrm{sw}}\right.$, the

346 ratio of the Li concentrations in the mussels to that in the water, Fig. 6A). These variations are 
347 significant, of about $2-3 \%$ (while the external error on the $\mathrm{Li}$ isotope ratio is $1.6 \%$ ). For all 348 individuals, $\mathrm{Li}_{\mathrm{m}} / \mathrm{Li}_{\mathrm{sw}}$ are higher than 1 , which agrees well with the bioaccumulation process 349 described previously. However, the regressions' slopes in Fig. 6A strongly depend on the 350 condition. Mussels exposed to low water Li concentrations (i.e. the CTRL and Li-0.5 groups) 351 display a positive slope, reflecting that $\Delta^{7} \mathrm{Li}_{\text {mussel-water }}$ increases when the individual enrichment 352 factor increases. On the other hand, mussels exposed to elevated seawater Li concentrations (> $\left.3531 \mu \mathrm{g} \mathrm{mL}{ }^{-1}\right)\left(\mathrm{Li}-1.0\right.$ and $\mathrm{Li}-1.5$ groups) display negative slopes (decreasing $\Delta^{7} \mathrm{Li}_{\text {mussel-water }}$ with the 354 enrichment factor). There is therefore a Li threshold between 0.5 and $1 \mu \mathrm{g} \mathrm{mL} \mathrm{L}^{-1}$, above which 355 mussels change their Li biological regulation. Under a significant but limited Li contamination $356\left(<1.0 \mu \mathrm{g} \mathrm{mL}^{-1}\right)$, the Li excess in the mussel results in a greater Li depuration, which may 357 correspond to a homeostasis mechanism operating to reduce the Li excess. In contrast, the 358 negative correlations observed for mussels exposed to seawater Li concentrations $>0.5 \mu \mathrm{g} \mathrm{mL}^{-1}$ 359 are best explained by a decrease of $R_{\phi}$ (Fig. 6A), indicating reduced Li excretion. Under these 360 conditions, mussels do not - or cannot - entirely eliminate excess Li. This threshold therefore 361 suggests a physiological shift, and we speculate that it may represent the onset of toxicity that is 362 the Li concentration beyond which mussels become "stressed".

363 Major element concentrations in the mussels' soft tissues also support a physiological effect 364 induced by Li contamination. Indeed, the principal component analysis (PCA, see Methods 365 section) shows that the essential elements $\mathrm{Na}, \mathrm{Ca}, \mathrm{Fe}$, and $\mathrm{K}$ correlate with each other on the 366 principal component 1 and are clearly distinct from $\Delta^{7} \mathrm{Li}_{\text {mussel-water, }} \mathrm{Li}_{\mathrm{m}}$, and $\mathrm{Li}_{\mathrm{sw}}$, which correlate 367 on the principal component 2. Figure 6B shows that the "intergroup" variability is discriminated 368 mostly by $\Delta^{7} \mathrm{Li}_{\text {mussel-water, }} \mathrm{Li}_{\mathrm{m}}$, and $\mathrm{Li}_{\mathrm{sw}}$, and therefore depends on the composition and 369 concentration of environmental $\mathrm{Li}$. On the other hand, the "intragroup" variability is mostly 
370 related to variations in essential (major) elements and depends on individual mussel metabolism.

371 This, altogether with the $\mathrm{Li}$ threshold highlighted by $\mathrm{Li}$ isotopes, strongly suggests a

372 physiological effect induced by Li contamination between 500 and $1000 \mu \mathrm{g} \mathrm{L}{ }^{-1}(0.5$ and $1 \mu \mathrm{g}$

$373 \mathrm{~mL}^{-1}$ ). Thus, our results demonstrate that, in addition to being a promising new proxy for $\mathrm{Li}$

374 contamination in coastal ecosystems, mussel Li concentrations and isotopic compositions might

375 also be used to assess Li toxicity since they respond to mussel adaptation and stress due to high

376 environmental Li concentrations. Studies on Li accumulation in organisms being at their infancy

377 and far from being fully understood, further studies would be needed to identify the underlying

378 regulation mechanisms in mussels facing Li contamination.

\section{Implications for coastal environments}

381 The highest dissolved Li concentrations $\left(>130000 \mu \mathrm{g} \mathrm{L}^{-1}\right)$ are found in surface waters that drain 382 the Salars, where Li is mined. Extensive studies of Chilean rivers show that they carry these 383 elevated Li concentrations down to the western Pacific Ocean. Their dissolved Li concentrations 384 are several orders of magnitude greater than those of other large rivers, and local estuaries 385 contain $\mathrm{Li}$ concentrations above $1000 \mu \mathrm{g} \mathrm{L^{-1 }}$ (100-1000 times more than other estuaries 386 worldwide). A published compedium ${ }^{68}$ shows that marine organisms from the Northern Chilean 387 littoral display Li concentrations considerably higher than those from other parts of the world 388 unrelated to salt flats - such as the French Atlantic coast or the Kerguelen Islands ${ }^{24}$. However, as 389 discussed in the previous section, $\mathrm{Li}$ isotopes indicate that this Li bioaccumulation has a cost 390 since there is a physiological shift above a threshold between 500 and $1000 \mu \mathrm{g} \mathrm{L}^{-1}$, which is the 391 minimum level found in waters of North Chilean estuaries. Li isotope compositions of marine 392 organisms from natural sites still need to be investigated, but given that the Li transfer to cells is 
393 essentially an active process ${ }^{57}$, passing this threshold may trigger abnormal growth patterns due 394 to chemical stress and damage induced by $\mathrm{Li}^{69}$.

395 Overall, these results highlight the need to monitor the evolution of these 'Li-rich' ecosystems, 396 for both their own sustainability, as well as for the local economy and human health. Inhabitants 397 of the Chilean coast consume 8 to 15 times more seafood and shellfish than inland populations, 398 while the proportion of other food types such as meat or vegetables are significantly less variable 399 between the two population groups ${ }^{68}$. This supports the need to quantify and better understand 400 how these coastal marine organisms bioaccumulate Li. The high Li concentrations measured in 401 North Chilean shellfish, fish, and drinking waters explain the high Li concentration measured in 402 the blood (serum), urine, and other tissues collected from the local population ${ }^{70}$. The effects 403 negative or positive - of these high Li levels in the diet are less known. Figuorea et al. ${ }^{68}$ 404 estimated that the local population eats about $20 \mathrm{~g} \mathrm{day}^{-1}$ of shellfish and seafood. With a Li 405 concentration of $100 \mu \mathrm{g} \mathrm{g}^{-1}$, as found in local mussels (Table 1), the Li intake is already $2000 \mu \mathrm{g}$ 406 day $^{-1}$ (twice the dose recommended by Schrauzer ${ }^{1}$ ). Given that vegetables, cereals, and waters 407 are also enriched in $\mathrm{Li}$ in this area, the $\mathrm{Li}$ intake by people living along North Chilean coast is 408 estimated to be close to the medical dose given to patient treated for neurodegenerative disease 409 (Table 1).

410 In other places in the world, the number of data measured in coastal waters and marine 411 organisms remains scarce, and it is difficult to estimate the impact of $\mathrm{Li}$ mining and 412 anthropogenic activities at the global scale. A recent study points that $\mathrm{Li}$ is not removed during 413 the waste water treatment plant process ${ }^{12}$. As described in the introduction, a significant level of 414 Li pollution has been documented in the Han River crossing Seoul ${ }^{12}$. The corresponding Li level 415 is still low compared to what is contained in North Chilean waters, but the predicted considerable 
416 increase of Li production for the next 10 years, along with the development of popular high

417 technology objects, may significantly increase Li levels in coastal environments if its recycling is

418 not massively developed.

419

\section{Conclusions}

421 This study demonstrates the ability of mussels to bioaccumulate Li, which implies that mussels 422 may be useful as biomonitoring organisms for Li pollution in coastal water. In addition, we

423 identify a preferential enrichment of ${ }^{7} \mathrm{Li}$ in mussel soft parts. A simple modeling allows us to 424 relate this Li heavy isotope enrichment to an enhanced NHE activity. Experimental data further 425 suggests that $\mathrm{Li}$ isotopes, more than Li concentrations, are useful to discriminate an organism's 426 metabolic or physiological threshold when facing high contaminant level in the environment. 427 Combined with ancillary environmental data, our experimental results have profound 428 implications for the fate of coastal ecosystems and shellfish consumption by population living in 429 high environmental Li regions. Finally, they also clarify how biological activity can impact the $430 \mathrm{Li}$ isotope compositions measured in calcitic shells and may bias the record of past ocean 431 variations. 


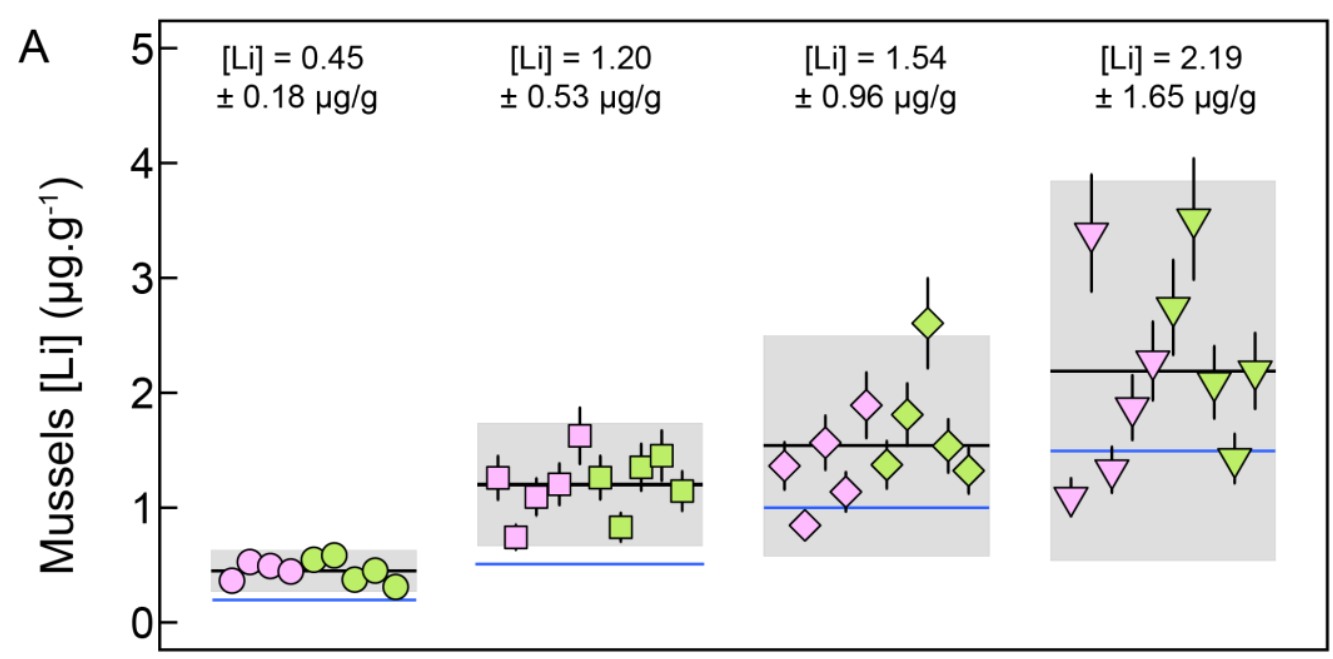

B

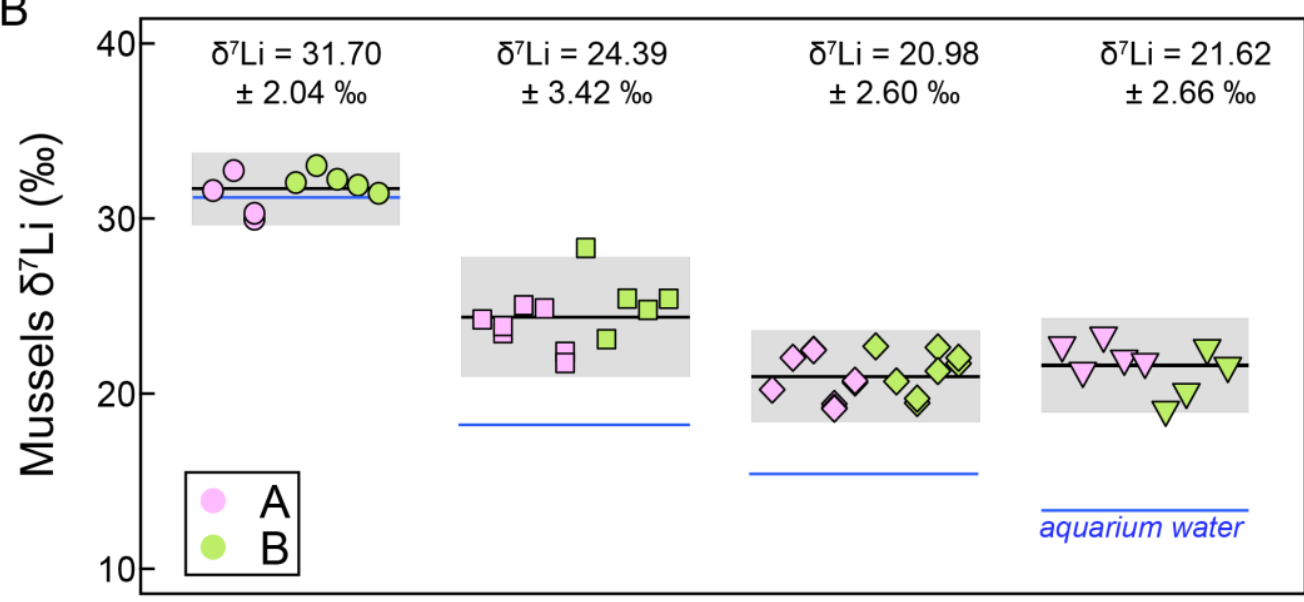

433 Figure 1: Li concentrations ([Li]) and isotopic compositions $\left(\delta^{7} \mathrm{Li}\right)$ of mussel soft tissues as a 434 function of water $\mathrm{Li}$ level. Blue mussels were exposed during 4 days to seawater with [ $\mathrm{Li}]=0.18$ $435 \mu \mathrm{g} \mathrm{mL}^{-1}$ (natural seawater, control group CTRL), $0.5 \mu \mathrm{g} \mathrm{mL}^{-1}$ (Li-0.5), $1.0 \mu \mathrm{g} \mathrm{mL}^{-1}$ (Li-1.0), or $4361.5 \mu \mathrm{g} \mathrm{mL}^{-1}(\mathrm{Li}-1.5)$. A (pink) and B (green) are the two experimental replicates. Reported errors 437 are $\pm 2 \mathrm{SD}$ ( $\mathrm{n}=10$ for $\mathrm{Li}-0.5$, Li-1.0, and $\mathrm{Li} 1.5 ; \mathrm{n}=9$ for CTRL). Replicates A and B display the 438 same average values (Wilcoxon test, $p>0.05$ ), within uncertainties. The seawater in each 439 experimental group is characterized by a distinct but constant $\delta^{7} \mathrm{Li}$ (blue lines). (A) The 440 variability of mussel Li concentrations increases from 44\%(CTRL) to 75\% (Li_1.5). 

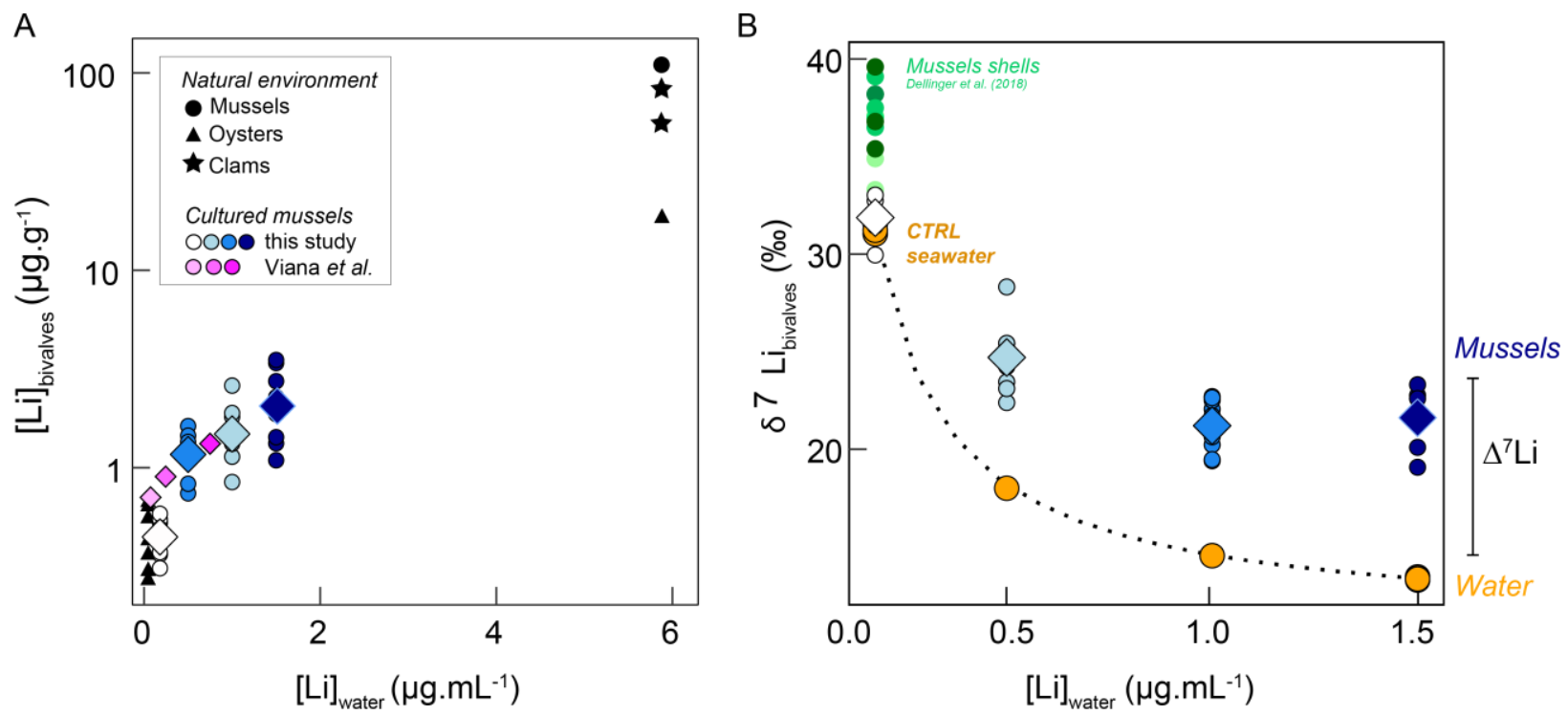

Figure 2: Observed Li bioconcentration and Li isotopic fractionation displayed by blue mussels

443 as a function of seawater Li concentration. (A) Mussel Li concentrations: circles and diamonds

444 indicate individual analyses and average values per experimental group, respectively. Black

445 symbols are for bivalves collected in their natural environment (the Bay of Biscay for those at

$4460.18 \mu \mathrm{g} \mathrm{mL}^{-1}[\mathrm{Li}]_{\text {water }}{ }^{24}$, and Rio Camarones in Chile for those at $6 \mu \mathrm{g} \mathrm{mL}{ }^{-1}[\mathrm{Li}]_{\text {water }}{ }^{68}$ ). Blue

447 tones symbol color indicates experimental group (i.e., Li concentration in seawater): white,

448 CTRL, $0.18 \mu \mathrm{g} \mathrm{Li} \mathrm{mL}{ }^{-1}$; light blue, Li-0.5, $0.5 \mu \mathrm{g} \mathrm{Li} \mathrm{mL}{ }^{-1}$; blue, Li-1.0, $1.0 \mu \mathrm{g} \mathrm{Li} \mathrm{mL}^{-1}$; and

449 dark blue, Li-1.5, $1.5 \mu \mathrm{g} \mathrm{Li} \mathrm{mL}^{-1}$. Pink tones symbol color are from Viana et al. ${ }^{71}$ (long-term Li

450 exposure experiment). (B) Mussel (symbols as in (A)) and water Li isotopic compositions

451 (orange circles). The dotted line shows the binary mixing curve between natural filtered seawater

$452\left(\delta^{7} \mathrm{Li}=31.2 \%\right)$ and the $\mathrm{Li}$ spike used in the experiment $\left(\delta^{7} \mathrm{Li}=10.8 \%\right.$ ). For comparison, $\mathrm{Li}$ 453 isotopic compositions of Mytilus eduli calcite shells collected in Cable Bay, UK, are also 454 reported in green (data from Freitas et al. ${ }^{65}$ and Dellinger et al. $^{35}$ ). These mussels were bred at 455 different water temperature from 11 to $20^{\circ} \mathrm{C}$, represented by the pale to dark green gradient. The $456 \mathrm{Li}$ concentration and $\delta^{7} \mathrm{Li}$ value of the seawater in which they grew is not known. 


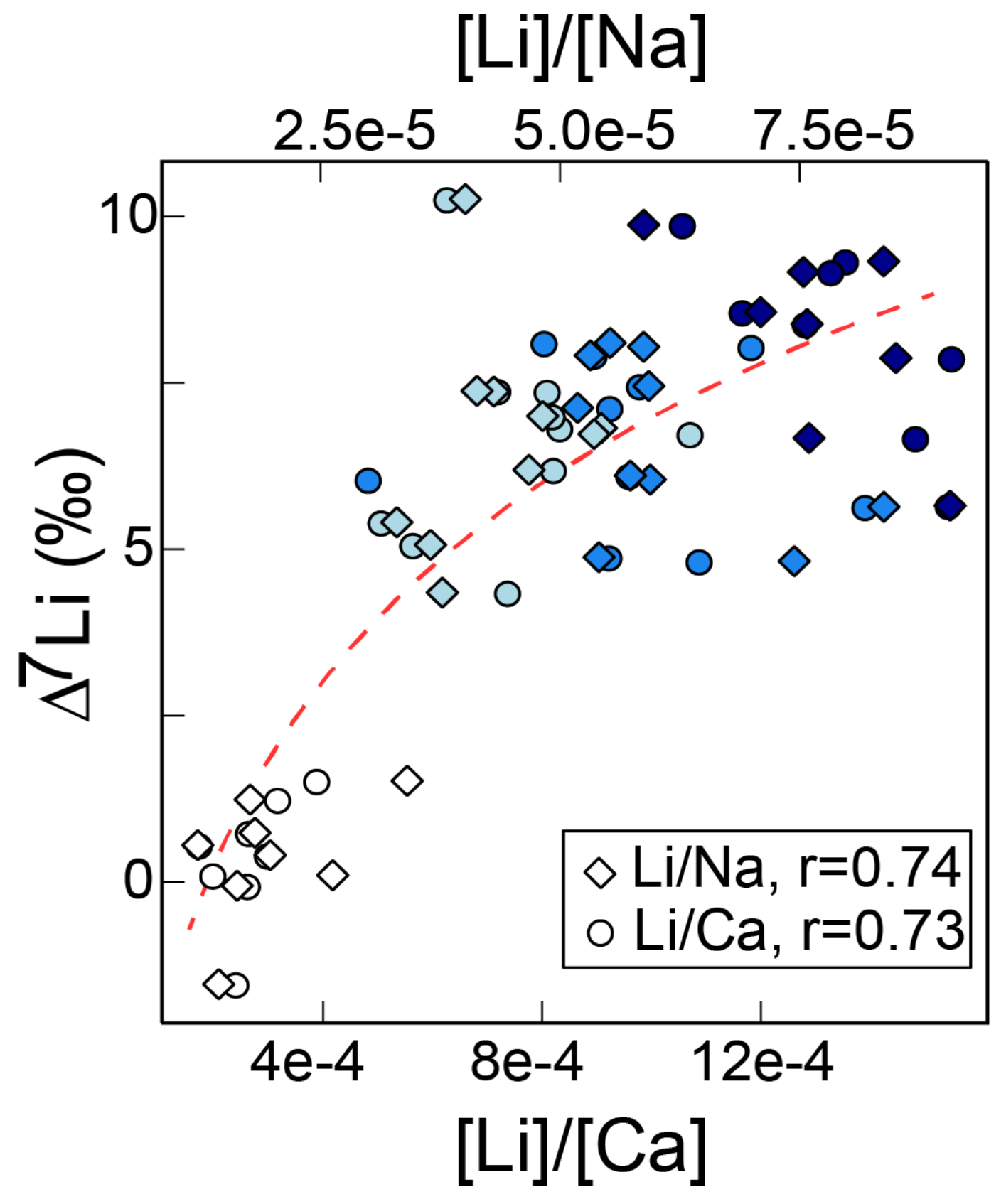

458 Figure 3: The effect of biological processing on mussel Li isotopic fractionations. $\Delta^{7} \mathrm{Li}_{\text {mussel-water }}$ 459 values determined in this study (symbol colors as in Fig. 2) as a function of Li/Ca (circles) and $460 \mathrm{Li} / \mathrm{Na}$ (diamonds) ratios in mussels. The red dashed line is the empirical positive correlation 461 between both parameters ( $\mathrm{r}=$ correlation coefficients). The $\mathrm{Ca} / \mathrm{Na}$ ratios measured in mussels 462 display a restricted range, on average $0.06 \pm 0.02(\mathrm{SD}, \mathrm{n}=38)$. 


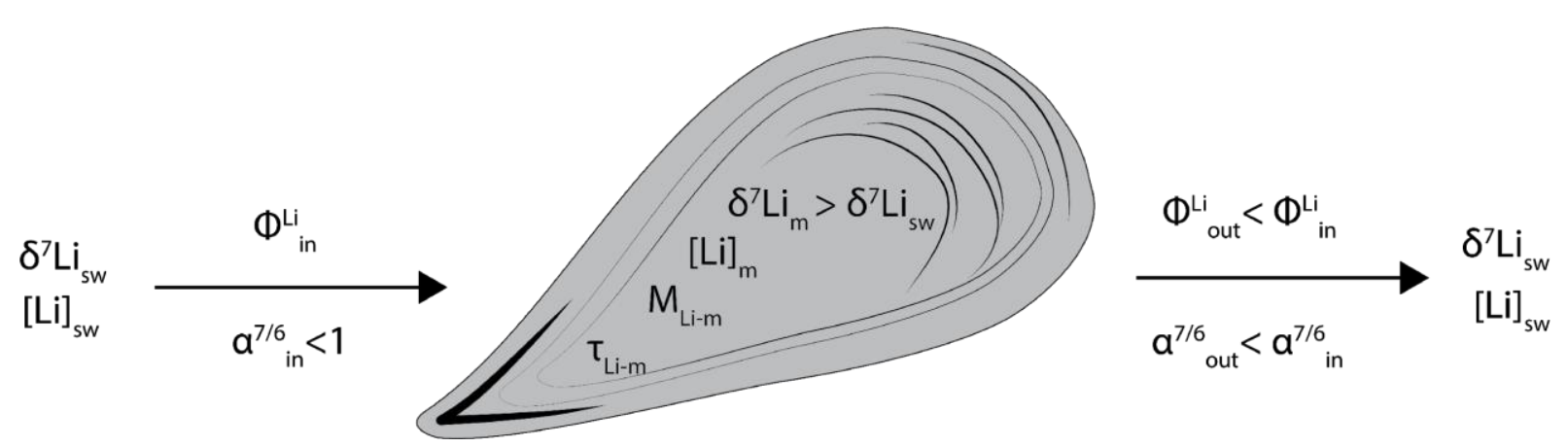

464 Figure 4: Box model of $\mathrm{Li}$ isotope composition in mussel soft tissue. Variables are: [Li], Li

465 concentration $\left(\mu \mathrm{g} \mathrm{g}^{-1}\right.$ or $\left.\mu \mathrm{g} \mathrm{mL}^{-1}\right) ; \mathrm{M}_{\mathrm{Li}}$, Li mass $(\mu \mathrm{g}) ; \delta^{7} \mathrm{Li}, \mathrm{Li}$ isotopic composition (\%o); $\tau_{\mathrm{Li}}, \mathrm{Li}$ 466 residence time $(\mathrm{d}) ; \alpha, \mathrm{Li}$ isotopic fractionation factor between mussel and water; $\alpha=$ $467 \quad\left({ }^{7} \mathrm{Li} /{ }^{6} \mathrm{Li}\right)_{\text {mussel }} /\left({ }^{7} \mathrm{Li} /{ }^{6} \mathrm{Li}\right)_{\text {water, }}$, which relates to $\Delta^{7} \mathrm{Li}$ as: $\Delta^{7} \mathrm{Li}_{\text {mussel-water }}=\delta^{7} \mathrm{Li}_{\text {mussel }}-\delta^{7} \mathrm{Li}_{\text {water }} \approx 1,000$ $468 \times \ln (\alpha) ; \alpha_{\text {in }}$ and $\alpha_{\text {out }}$ represent the magnitude of Li isotopic fractionations during uptake and 469 excretion, respectively; and $\phi_{\mathrm{Li}}, \mathrm{Li}$ flux $\left(\mu \mathrm{g} \mathrm{d}^{-1}\right)$. Subscripts are: $\mathrm{m}$, mussel; sw, seawater; in, 470 input; and out, output. Using the equations developed in the Supplementary Material, the best 471 average $\delta^{7} \mathrm{Li}_{\mathrm{m} \text {-mod }}$ values (i.e., modeled $\delta^{7} \mathrm{Li}_{\text {mussel }}$ values) for each experimental condition were 472 determined by minimizing the difference between the modeled and measured $\delta^{7} \mathrm{Li}$ values (i.e., $\left.473 \quad \delta^{7} \mathrm{Li}_{\mathrm{m}-\mathrm{mod}}-\delta^{7} \mathrm{Li}_{\mathrm{m} \text {-meas }}\right)$, with $\alpha_{\text {out }}$ and $\alpha_{\text {in }}$ ranging between 0.9 and 1. 


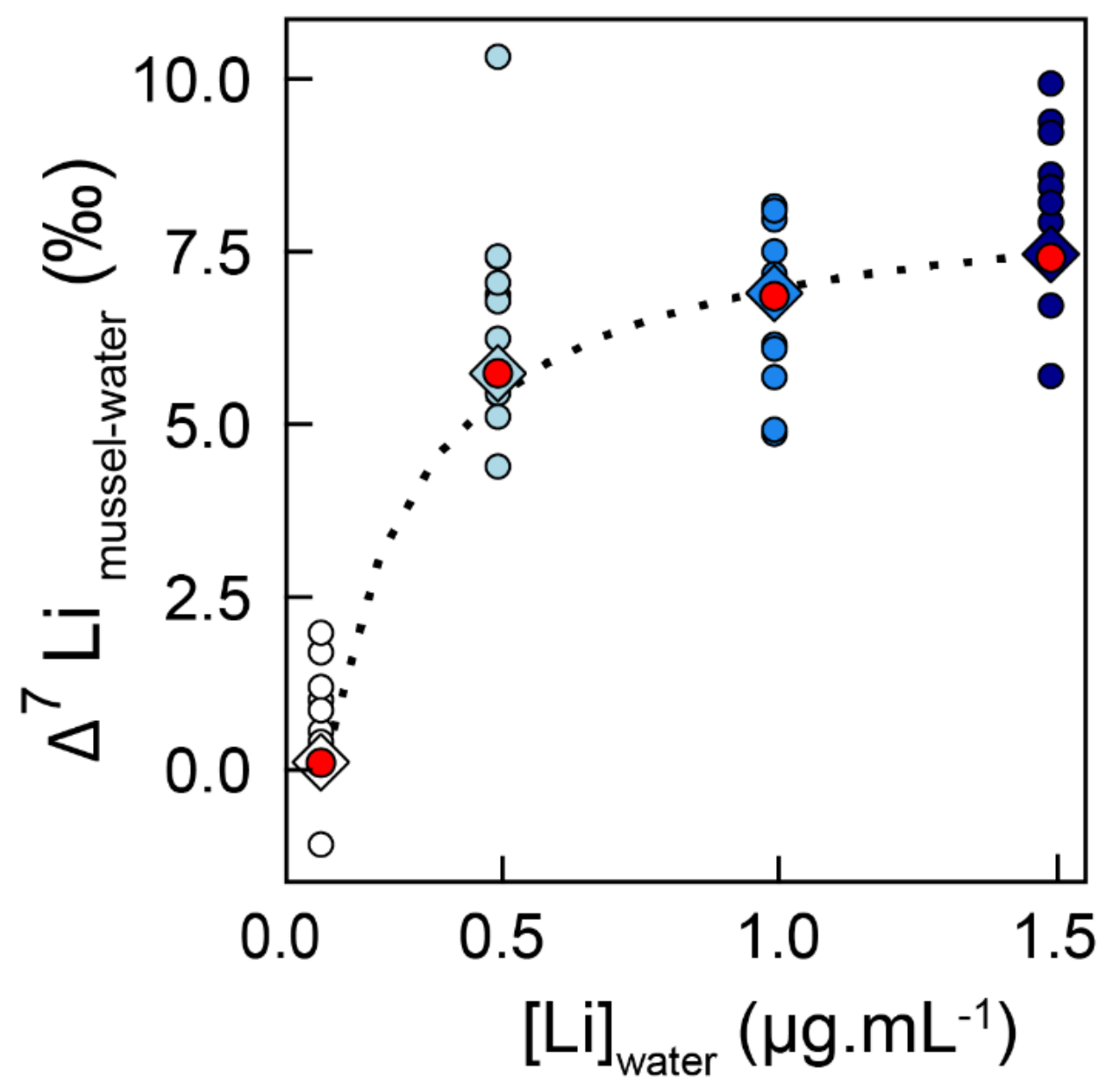

475 Figure 5: Observed and modeled $\mathrm{Li}$ isotopic fractionations in mussels as a function of seawater

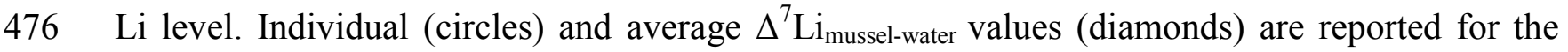

477 four experimental conditions. Red circles display the modeled isotope fractionations calculated 478 by the box model detailed in the text and in the Supplementary Material. 

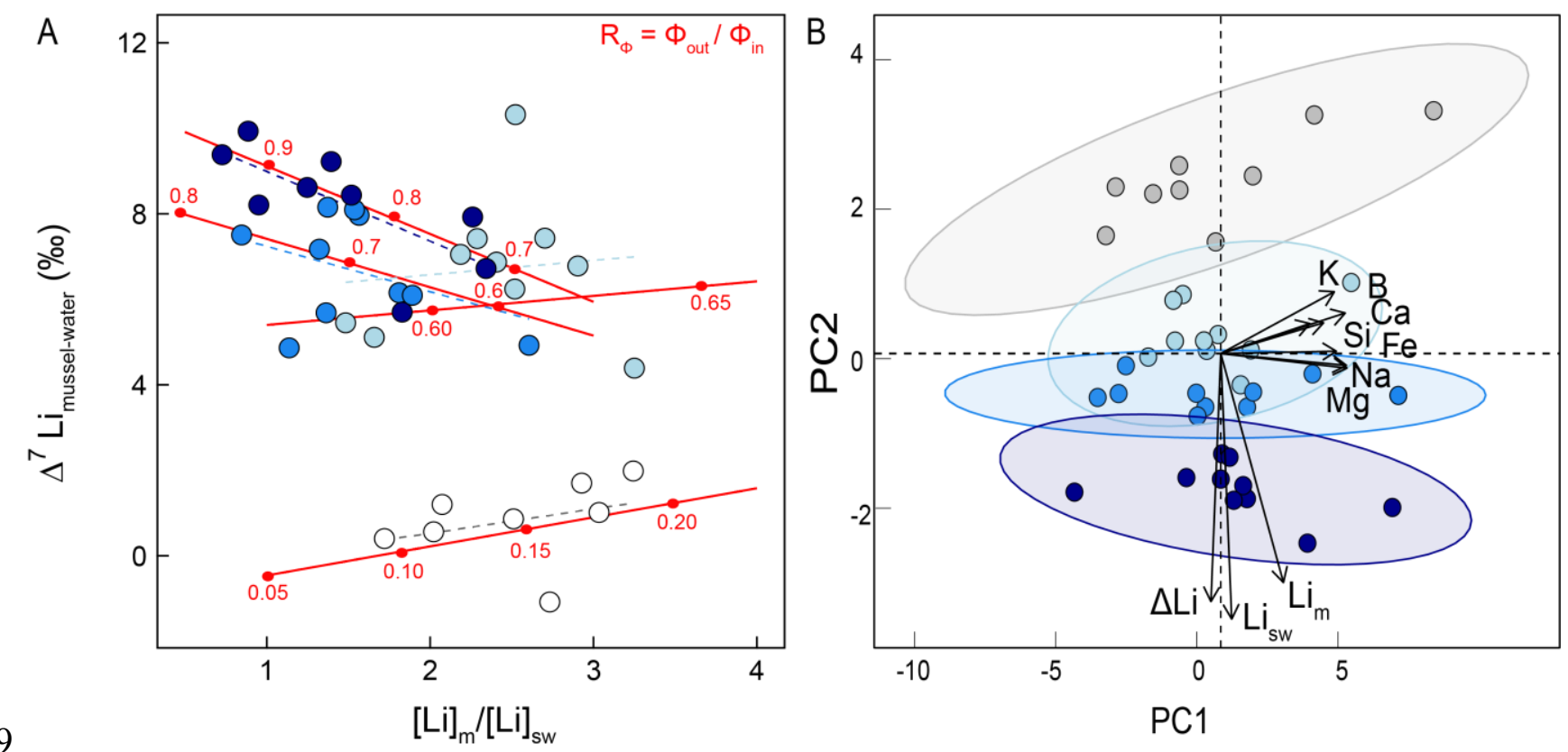

480 Figure 6: The controls of $\mathrm{Li}$ excretion/intake rate and of essential elements on mussel-water $\mathrm{Li}$

481 isotopic fractionation. (A) $\Delta^{7} \mathrm{Li}_{\text {mussel-water }} \mathrm{vs}$. $\mathrm{Li}$ enrichment factor (i.e., the ratio of the $\mathrm{Li}$

482 concentration in mussels to that in water, equivalent to the bioaccumulation factor or partition

483 coefficient between mussels and seawater). Symbol colors indicate the experimental conditions

484 as in Fig. 2. Solid lines are intragroup linear regressions. Mussels exposed to relatively Li-poor

485 conditions (CTRL and Li-0.5 groups) show positive slopes, whereas those exposed to Li-rich

486 conditions (Li-1.0 and Li-1.5 groups) define negative slopes. Red lines display model variations

487 and red dots indicate specific $\mathrm{R}_{\phi}$ values. (B) Principal component analysis (PCA) of all mussels

488 (symbols as in (A), shaded ellipses represent intragroup variability). PC1 and PC2 are principal

489 components 1 and 2. Arrow length is proportional to the percentage contribution of these first

490 two principal components to the observed variation of each variable. PC1 and PC2 represent

$49175 \%$ of the variability in the dataset. Variables can be separated into three groups: mussel B, Ca,

$492 \mathrm{Fe}, \mathrm{K}, \mathrm{Mg}, \mathrm{Na}$, and $\mathrm{Si}$ concentrations on $\mathrm{PC} 1$ and $\Delta^{7} \mathrm{Li}_{\text {mussel-water, }} \mathrm{Li}_{\mathrm{m}}$, and $\mathrm{Li}_{\mathrm{sw}}$ on PC2. 
Table 1: Compilation of Li concentrations and fluxes estimated for several contexts.

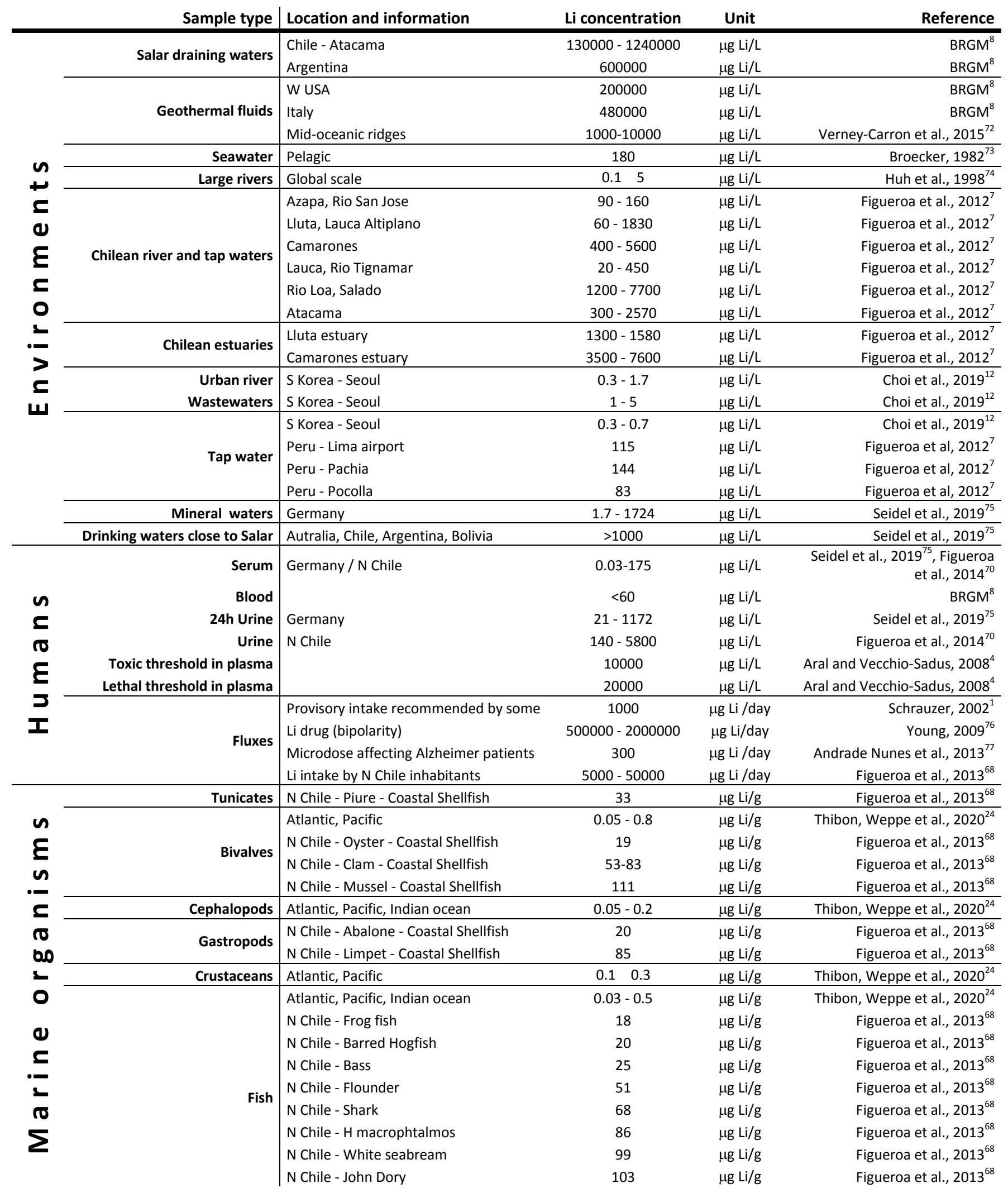




\section{Supporting Information.}

497 Supplementary Material is available and contents supplementary figures, data tables, and box 498 model equations.

501 AUTHOR INFORMATION

502 Corresponding Author

$503 *$ fanny.thibon@osb-vlfr.fr

\section{Author Contributions}

505 N. Vigier and M. Metian led the project. F. Oberhänsli, E. Vassileva, and A.M. Orani performed 506 sample preparation and Li concentration measurements. M. Montanes, N. Vigier, and P. Telouk 507 performed the sample Li purification and Li isotopic ratio measurements. F. Thibon modeled the 508 data and wrote the original draft of the manuscript. F. Thibon, N. Vigier, M. Metian, and P. 509 Swarzenski contributed to review and editing the manuscript. All authors have given approval to 510 the final version of the manuscript.

\section{ACKNOWLEDGMENT}

513 We acknowledge financial support from the ANR ISO2MET (//anr.fr/Projet-ANR-18-CE34514 0002; www.iso2met-project.fr/) and access to facilities provided by the International Atomic 515 Energy Agency (IAEA) of Monaco and the CNRS-INSU at ENS-Lyon. The IAEA is grateful for 
516 the support provided to its Environment Laboratories by the Government of the Principality of

517 Monaco. We also thank a lot Steeve Comeau for his help reworking this manuscript.

518

519 TOC GRAPHIC

520

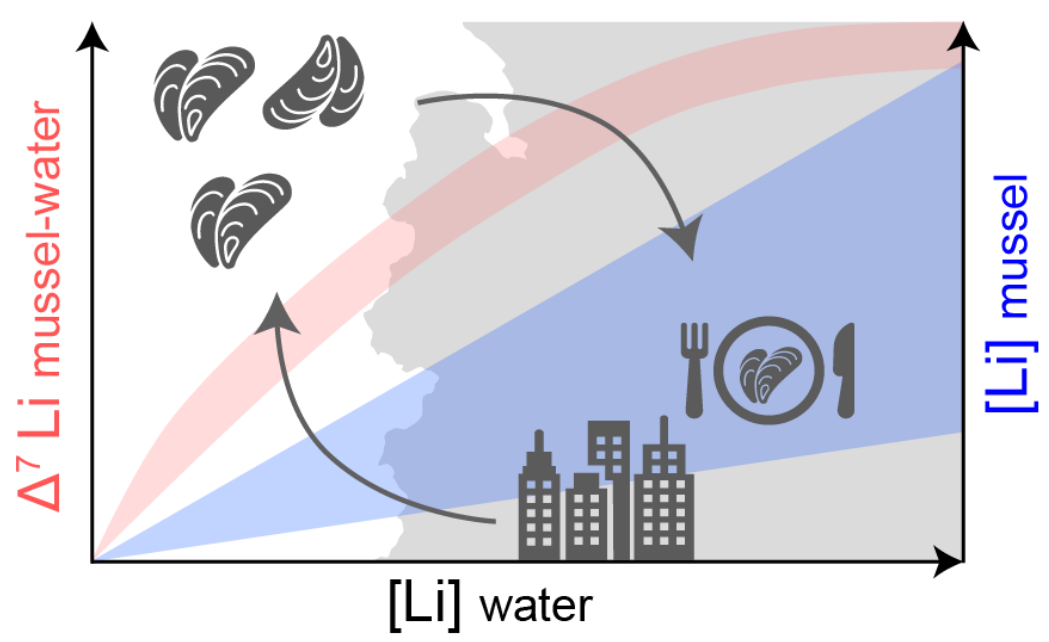


523 (1) Schrauzer, G. N. Lithium: Occurrence, Dietary Intakes, Nutritional Essentiality. Journal of the American College of Nutrition 2002, $\quad 21$

(1), 14-21. https://doi.org/10.1080/07315724.2002.10719188.

(2) Egorova, K. S.; Ananikov, V. P. Toxicity of Metal Compounds: Knowledge and Myths. Organometallics 2017, 36 (21), 4071-4090. https://doi.org/10.1021/acs.organomet.7b00605.

(3) Zoroddu, M. A.; Aaseth, J.; Crisponi, G.; Medici, S.; Peana, M.; Nurchi, V. M. The Essential Metals for Humans: A Brief Overview. Journal of Inorganic Biochemistry 2019, 195, 120-129. https://doi.org/10.1016/j.jinorgbio.2019.03.013.

(6) Schou, M.; Amdisen, A.; Trap-Jensen, J. Lithium Poisoning. American Journal of Psychiatry 1968, 125 (4), 520-527. https://doi.org/10.1176/ajp.125.4.520.

(7) Figueroa, L.; Barton, S.; Schull, W.; Razmilic, B.; Zumaeta, O.; Young, A.; Kamiya, Y.; Hoskins, J.; Ilgren, E. Environmental Lithium Exposure in the North of Chile--I. Natural Water Sources.

542 (8) Labbé, J. F.; Daw, G. Panorama 2011 Du Marché Du Lithium. BRGM 2012.

543 (9) Leguérinel, M.; Lefebvre, G.; Christmann, P. Compétition Entre Secteurs Industriels Pour l'accès $544 \quad$ Aux Matières Premières, 2018. 
(10) Mohr, S. H.; Mudd, G. M.; Giurco, D. Lithium Resources and Production: Critical Assessment and Global Projections. Minerals 2012, 2 (1), 65-84. https://doi.org/10.3390/min2010065.

(11) Kszos, L. A.; Stewart, A. J. Review of Lithium in the Aquatic Environment: Distribution in the United States, Toxicity and Case Example of Groundwater Contamination. Ecotoxicology 2003, 12 (5), 439-447. https://doi.org/10.1023/a:1026112507664.

(12) Choi, H.-B.; Ryu, J.-S.; Shin, W.-J.; Vigier, N. The Impact of Anthropogenic Inputs on Lithium

(13) Decarreau, A.; Vigier, N.; Pálková, H.; Petit, S.; Vieillard, P.; Fontaine, C. Partitioning of Lithium

(15) Hogan, J. F.; Blum, J. D. Boron and Lithium Isotopes as Groundwater Tracers: A Study at the Fresh

(16) Pogge von Strandmann, P. A. E.; Burton, K. W.; James, R. H.; van Calsteren, P.; Gíslason, S. R.;

(14) Schwab, A. B.; O’Connell, M. E.; Long, S. E. The Use of Lithium Concentration Data and Isotopic Ratios as Hydrologic Tracers in a First-Order Catchment. Geol Soc Am Prog Abst 1995, 27, A97.

(17) Yang, C.; Yang, S.; Vigier, N.; Lian, E.; Lai, Z. Behavior of Li Isotopes along a 2D Transect in the 566 
(18) Phillips, D. J. H. The Common Mussel Mytilus Edulis as an Indicator of Pollution by Zinc, Cadmium,

Lead and Copper. I. Effects of Environmental Variables on Uptake of Metals. Marine Biology 1976, 38 (1), 59-69. https://doi.org/10.1007/bf00391486.

(19) Shi, D.; Wang, W.-X. Modification of Trace Metal Accumulation in the Green Mussel Perna Viridis

by Exposure to $\mathrm{Ag}, \mathrm{Cu}$, and $\mathrm{Zn}$. Environmental Pollution 2004, 132 (2), 265-277.

(20) Viarengo, A.; Canesi, L. Mussels as Biological Indicators of Pollution. Aquaculture 1991, 94 (2), 225-243. https://doi.org/10.1016/0044-8486(91)90120-V.

(21) Claisse, D.; Arnold, M.; Jean-Yves, Q. Le Réseau National d'observation de La Qualité Du Milieu Marin (RNO). Analusis Magazine 1992, 20 (6), 19-22.

(22) Goldberg, E. The Mussel Watch - A First Step in Global Marine Monitoring. Marine Pollution Bulletin 1975, 6, 111-111. https://doi.org/10.1016/0025-326x(75)90271-4.

(23) Kimbrough, K. L.; Lauenstein, G.; Christensen, J.; Apeti, D. An Assessment of Two Decades of Contaminant Monitoring in the Nation's Coastal Zone. 2008.

(24) Thibon, F.; Weppe, L.; Vigier, N.; Churlaud, C.; Lacoue-Labarthe, T.; Metian, M.; Cherel, Y.; Bustamante, P. Large-Scale Survey of Lithium Concentrations in Marine Organisms. Science of The Total Environment 2021, 751, 141453. https://doi.org/10.1016/j.scitotenv.2020.141453.

(25) Albarède, F. Metal Stable Isotopes in the Human Body: A Tribute of Geochemistry to Medicine. Elements 2015, 11 (4), 265-269. https://doi.org/10.2113/gselements.11.4.265.

(26) Balter, V.; da Costa, A. N.; Bondanese, V. P.; Jaouen, K.; Lamboux, A.; Sangrajrang, S.; Vincent, N.; of Hepatocellular Carcinoma Patients. Proceedings of the National Academy of Sciences 2015, 112 (4), 982-985. 
(27) Costas-Rodríguez, M.; Delanghe, J.; Vanhaecke, F. High-Precision Isotopic Analysis of Essential Mineral Elements in Biomedicine: Natural Isotope Ratio Variations as Potential Diagnostic and/or Prognostic Markers. Trends in Analytical Chemistry 2016, 76, 182-193. https://doi.org/10.1016/j.trac.2015.10.008.

(28) Vanhaecke, F.; Costas-Rodriguez, M. What's up Doc? - High-Precision Isotopic Analysis of Essential Metals in Biofluids for Medical Diagnosis. spectroscopyeurope 2015, 27 (3), 11-14.

(29) Balter, V.; Vigier, N. Natural Variations of Lithium Isotopes in a Mammalian Model. Metallomics 2014, 6 (3), 582-586.

(30) Hathorne, E. C.; James, R. H. Temporal Record of Lithium in Seawater: A Tracer for Silicate Weathering? Earth and Planetary Science Letters 2006, 246 (3-4), 393-406. https://doi.org/10.1016/j.epsl.2006.04.020.

(31) Li, G.; West, A. J. Evolution of Cenozoic Seawater Lithium Isotopes: Coupling of Global Denudation Regime and Shifting Seawater Sinks. Earth and Planetary Science Letters 2014, 401, 284-293. https://doi.org/10.1016/j.epsl.2014.06.011.

(32) Misra, S.; Froelich, P. N. Lithium Isotope History of Cenozoic Seawater: Changes in Silicate Weathering and Reverse Weathering. Science 2012, 335 (6070), 818-823. https://doi.org/10.1126/science.1214697.

607 (33) Vigier, N.; Godderis, Y. A New Approach for Modeling the Cenozoic Oceanic Lithium Isotope Paleo-Variations: The Key Role of Climate. Climate of the Past Discussions 2014, 10 (4). https://doi.org/10.5194/cp-11-635-2015.

610 (34) Wanner, C.; Sonnenthal, E. L.; Liu, X.-M. Seawater $\delta^{7}$ Li: A Direct Proxy for Global $\mathrm{CO}_{2}$ 611 Consumption by Continental Silicate Weathering? Chemical geology 2014, 381, $154-167$. https://doi.org/10.1016/j.chemgeo.2014.05.005. 
613 (35) Dellinger, M.; West, A. J.; Paris, G.; Adkins, J. F.; Pogge von Strandmann, P. A. E.; Ullmann, C. V.;

614 Eagle, R. A.; Freitas, P.; Bagard, M.-L.; Ries, J. B.; Corsetti, F. A.; Perez-Huerta, A.; Kampf, A. R. The Li Isotope Composition of Marine Biogenic Carbonates: Patterns and Mechanisms. Geochimica et Cosmochimica Acta 2018, 236, 315-335. https://doi.org/10.1016/j.gca.2018.03.014.

(36) Roberts, J.; Kaczmarek, K.; Langer, G.; Skinner, L.; Bijma, J.; Bradbury, H.; Turchyn, A.; Lamy, F.; Misra, S. Lithium Isotopic Composition of Benthic Foraminifera: A New Proxy for Paleo-PH Reconstruction. Geochimica et Cosmochimica Acta 2018, 236, 336-350.

(37) Thébault, J.; Chauvaud, L. Li/Ca Enrichments in Great Scallop Shells (Pecten Maximus) and Their Relationship with Phytoplankton Blooms. Palaeogeography, Palaeoclimatology, Palaeoecology 2012, 373, 108-122. https://doi.org/10.1016/j.palaeo.2011.12.014.

(38) Vigier, N.; Rollion-Bard, C.; Levenson, Y.; Erez, J. Lithium Isotopes in Foraminifera Shells as a Novel Proxy for the Ocean Dissolved Inorganic Carbon (DIC). Comptes Rendus Geoscience 2015, 347 (1), 43-51. https://doi.org/10.1016/j.crte.2014.12.001.

(39) Pogge von Strandmann, P. A. E.; Jenkyns, H. C.; Woodfine, R. G. Lithium Isotope Evidence for Enhanced Weathering during Oceanic Anoxic Event 2. Nature Geoscience 2013, 6 (8), 668-672. https://doi.org/10.1038/ngeo1875.

(40) Sezer, N.; Kılı̧̧, Ö.; Metian, M.; Belivermiş, M. Effects of Ocean Acidification on 109Cd, 57Co, and 134Cs Bioconcentration by the European Oyster (Ostrea Edulis): Biokinetics and Tissue-toSubcellular Partitioning. Journal of Environmental Radioactivity 2018, 192, 376-384. https://doi.org/10.1016/j.jenvrad.2018.07.011.

(41) Metian, M.; Pouil, S.; Hédouin, L.; Oberhänsli, F.; Teyssié, J.-L.; Bustamante, P.; Warnau, M. Differential Bioaccumulation of 134Cs in Tropical Marine Organisms and the Relative Importance 
of Exposure Pathways. Journal of Environmental Radioactivity 2016, 152, 127-135. https://doi.org/10.1016/j.jenvrad.2015.11.012.

(42) Metian, M.; Warnau, M.; Teyssié, J.-L.; Bustamante, P. Characterization of 241Am and 134Cs

(43) Nagato, E. G.; D’eon, J. C.; Lankadurai, B. P.; Poirier, D. G.; Reiner, E. J.; Simpson, A. J.; Simpson,

(47) Vigier, N.; Decarreau, A.; Millot, R.; Carignan, J.; Petit, S.; France-Lanord, C. Quantifying Li Isotope https://doi.org/10.1016/j.chemosphere.2013.04.085.

(44) Cresswell, T.; Metian, M.; Golding, L. A.; Wood, M. D. Aquatic Live Animal Radiotracing Studies for Ecotoxicological Applications: Addressing Fundamental Methodological Deficiencies. Journal of $\begin{array}{llll}\text { Environmental } & \text { Radioactivity } & \text { 2017, }\end{array}$ https://doi.org/10.1016/j.jenvrad.2017.05.017.

(45) Magnusson, B. The Fitness for Purpose of Analytical Methods: A Laboratory Guide to Method Validation and Related Topics (2nd Ed. 2014); Eurachem, 2014.

(46) Kragten, J. Tutorial Review. Calculating Standard Deviations and Confidence Intervals with a Universally Applicable Spreadsheet Technique. Analyst 1994, 119 (10), 2161-2165. https://doi.org/10.1039/AN9941902161. Cosmochimica Acta 2008, 72 (3), 780-792. https://doi.org/10.1016/j.gca.2007.11.011. 
658 (48) Bastian, L.; Vigier, N.; Reynaud, S.; Kerros, M.-E.; Revel, M.; Bayon, G. Lithium Isotope Composition of Marine Biogenic Carbonates and Related Reference Materials. Geostandards and Geoanalytical Research 2018, 42 (3), 403-415. https://doi.org/10.1111/ggr.12218.

(49) R Core Team. R: A Language and Environment for Statistical Computing. $R$ Foundation for Statistical Computing, Vienna, Austria. URL https://www. R-project. org 2017.

(50) Millot, R.; Guerrot, C.; Vigier, N. Accurate and High-Precision Measurement of Lithium Isotopes in

Two Reference Materials by MC-ICP-MS. Geostandards and Geoanalytical Research 2004, 28 (1), 153-159. https://doi.org/10.1111/j.1751-908X.2004.tb01052.x.

(51) Carignan, J.; Vigier, N.; Millot, R. Three Secondary Reference Materials for Lithium Isotope Measurements: Li7-N, Li6-N and LiCl-N Solutions. Geostandards and Geoanalytical Research 2007, 31 (1), 7-12. https://doi.org/10.1111/j.1751-908X.2007.00833.x.

(52) Thibon, F.; Weppe, L.; Vigier, N.; Churlaud, C.; Lacoue-Labarthe, T.; Metian, M.; Cherel, Y.; Bustamante, P. Large Scale Survey of Lithium Concentrations in Marine Organisms. Stoten under review.

(53) Warnau, M.; Teyssié, J.-L.; Fowler, S. W. Cadmium Bioconcentration in the Echinoid Paracentrotus Lividus: Influence of the Cadmium Concentration in Seawater. Marine Environmental Research 1997, 43 (4), 303-314. https://doi.org/10.1016/S0141-1136(96)00093-1.

(54) Apeti, D. A.; Lauensteirn, G. G.; Johnson, E.; Kimbrough, K.; Mason, A. L. Mussel Watch Sampling Procedures and Site Descriptions for Oregon State. 2017. https://doi.org/10.25923/DAJ6-KK55.

677 (55) Johnson, C. M.; Beard, B. L.; Albarède, F. Geochemistry of Non-Traditional Stable Isotopes; 2004; Vol. 55.

(56) Bouret, Y.; Poet, M.; Vigier, N.; Counillon, L.; Jarretou, G.; Bendahhou, S.; Montanes, M.; Thibon, F.; Balter, V. Biological Fractionations of Lithium Isotopes by Cellular Ion Exchangers Demonstrate Novel Modes of Transport. submitted 2021. 
682 (57) Counillon, L.; Bouret, Y.; Marchiq, I.; Pouyssegur, J. $\mathrm{Na}^{+} / \mathrm{H}^{+}$Antiporter (NHE1) and Lactate $/ \mathrm{H}^{+}$ Symporters (MCTs) in PH Homeostasis and Cancer Metabolism. Biochimica et Biophysica Acta (BBA)-Molecular Cell Research 2016, $1863 \quad$ (10), 2465-2480. https://doi.org/10.1016/j.bbamcr.2016.02.018.

(58) Grinstein, S.; Rotin, D.; Mason, M. J. $\mathrm{Na}^{+} / \mathrm{H}^{+}$Exchange and Growth Factor-Induced Cytosolic PH Changes. Role in Cellular Proliferation. Biochimica et Biophysica Acta (BBA)-Reviews on Biomembranes 1989, 988 (1), 73-97. https://doi.org/10.1016/0304-4157(89)90004-X.

(59) Milosavljevic, N.; Monet, M.; Léna, I.; Brau, F.; Lacas-Gervais, S.; Feliciangeli, S.; Counillon, L.; Poët, M. The Intracellular $\mathrm{Na}^{+} / \mathrm{H}^{+}$Exchanger NHE7 Effects a $\mathrm{Na}^{+}$-Coupled, but Not $\mathrm{K}^{+}$-Coupled Proton-Loading Mechanism in Endocytosis. Cell reports 2014, 7 (3), 689-696.

(60) Jakobsson, E.; Argüello-Miranda, O.; Chiu, S.-W.; Fazal, Z.; Kruczek, J.; Nunez-Corrales, S.; Pandit, S.; Pritchet, L. Towards a Unified Understanding of Lithium Action in Basic Biology and Its Significance for Applied Biology. J Membr Biol 2017, 250 (6), 587-604. https://doi.org/10.1007/s00232-017-9998-2.

(61) Herchuelz, A.; Van Eylen, F.; Lebrun, P. L'échange Na/Ca. médecine/science 1995, 11, 232-238.

(62) Palty, R.; Ohana, E.; Hershfinkel, M.; Volokita, M.; Elgazar, V.; Beharier, O.; Silverman, W. F.; Argaman, M.; Sekler, I. Lithium-Calcium Exchange Is Mediated by a Distinct PotassiumIndependent Sodium-Calcium Exchanger. Journal of Biological Chemistry 2004, 279 (24), 2523425240. https://doi.org/10.1074/jbc.M401229200.

702 Coral Skeletons. Chemical Geology 2015, 396, 98-111. 
(64) Rollion-Bard, C.; Vigier, N.; Meibom, A.; Blamart, D.; Reynaud, S.; Rodolfo-Metalpa, R.; Martin, S.; Gattuso, J.-P. Effect of Environmental Conditions and Skeletal Ultrastructure on the Li Isotopic Composition of Scleractinian Corals. Earth and Planetary Science Letters 2009, 286 (1-2), 63-70. https://doi.org/10.1016/j.epsl.2009.06.015.

(65) Freitas, P. S.; Clarke, L.; Kennedy, H.; Richardson, C. Inter- and Intra-Specimen Variability Masks Reliable Temperature Control on Shell Mg/Ca Ratios in Laboratory- and Field-Cultured Mytilus Edulis and Pecten Maximus (Bivalvia). 2008. https://doi.org/10.5194/BG-5-1245-2008.

Marriott, C. S.; Henderson, G. M.; Belshaw, N. S.; Tudhope, A. W. Temperature Dependence of $\Delta 7 \mathrm{Li}, \Delta 44 \mathrm{Ca}$ and $\mathrm{Li} / \mathrm{Ca}$ during Growth of Calcium Carbonate. Earth and Planetary Science Letters 2004, $222(2)$.

(67) Stokes, P. E.; Okamoto, M.; Lieberman, K. W.; Alexander, G.; Triana, E. Stable Isotopes of Lithium: In Vivo Differential Distribution between Plasma and Cerebrospinal Fluid. Biol. Psychiatry 1982, $17(4), 413-421$.

(68) Figueroa, L. T.; Razmillic, B.; Zumeata, O.; Aranda, G. N.; Barton, S. A.; Schull, W. J.; Young, A. H.; Kamiya, Y. M.; Hoskins, J. A.; Ilgren, E. B. Environmental Lithium Exposure in the North of Chile--II. Natural Food Sources. Biol Trace Elem Res 2013, 151 (1), 122-131. https://doi.org/10.1007/s12011-012-9543-1.

(69) Roux, M.; Dosseto, A. From Direct to Indirect Lithium Targets: A Comprehensive Review of Omics Data. Metallomics 2017, 9 (10), 1326-1351. https://doi.org/10.1039/C7MT00203C.

724 (70) Figueroa, L. T.; Barton, S. A.; Schull, W. J.; Young, A. H.; Kamiya, Y. M.; Hoskins, J. A.; Ilgren, E. B. Environmental Lithium Exposure in the North of Chile - Tissue Exposure Indices. Epidemiology, Biostatistics and Public Health 2014, 11 (1). https://doi.org/10.2427/8847. 
727 (71) Viana, T.; Ferreira, N.; Henriques, B.; Leite, C.; De Marchi, L.; Amaral, J.; Freitas, R.; Pereira, E. How Safe Are the New Green Energy Resources for Marine Wildlife? The Case of Lithium.

(72) Verney-Carron, A.; Vigier, N.; Millot, R.; Hardarson, B. S. Lithium Isotopes in Hydrothermally Altered Basalts from Hengill (SW Iceland). Earth and Planetary Science Letters 2015, 411, 62-71.

(73) Broecker, W. S.; Peng, T.-H. Tracers in the Sea; Eldigio Press: Palisades, N.Y., 1982.

734 (74) Huh, Y.; Chan, L.-H.; Zhang, L.; Edmond, J. M. Lithium and Its Isotopes in Major World Rivers: Implications for Weathering and the Oceanic Budget. Geochimica et Cosmochimica Acta 1998, 62,

(75) Seidel, U.; Baumhof, E.; Hägele, F. A.; Bosy-Westphal, A.; Birringer, M.; Rimbach, G. Lithium-Rich Mineral Water Is a Highly Bioavailable Lithium Source for Human Consumption. Molecular Nutrition \& Food Research 2019, 63 (13), 1900039. https://doi.org/10.1002/mnfr.201900039.

(76) Young, W. Review of Lithium Effects on Brain and Blood. Cell Transplant 2009, 18 (9), 951-975. https://doi.org/10.3727/096368909X471251.

742 (77) Nunes, M. A.; Buck, T. A. V. and H. S. Microdose Lithium Treatment Stabilized Cognitive 743 Impairment in Patients with Alzheimer's Disease https://www.eurekaselect.com/106398/article (accessed Oct 19, 2020). 